\title{
Vulnerability of national economies to the impacts of climate change on fisheries
}

\author{
Edward H. Allison ${ }^{1,2}$, Allison L. Perry ${ }^{1,3}$, Marie-Caroline Badjeck ${ }^{1,4}$, W. Neil Adger ${ }^{5}$, Katrina Brown ${ }^{2,5}$, Declan \\ Conway $^{2,5}$, Ashley S. Halls ${ }^{6}$, Graham M. Pilling ${ }^{7}$, John D. Reynolds ${ }^{8}$, Neil L. Andrew ${ }^{1}$ E Nicholas K. Dulvy ${ }^{7,8}$

\begin{abstract}
${ }^{1}$ The WorldFish Center, GPO Box 500, Penang, Malaysia; ${ }^{2}$ School of Development Studies, University of East Anglia, Norwich, NR4 7TJ, UK; ${ }^{3}$ School of Biological Sciences, University of East Anglia, Norwich, NR4 7TJ, UK; ${ }^{4}$ Zentrum für Marine Tropenökologie, University of Bremen, 28359 Bremen, Germany; ${ }^{5}$ Tyndall Centre for Climate Change Research, School of Environmental Sciences, University of East Anglia, Norwich, NR4 7TJ, UK; ${ }^{6}$ Mekong River Commission, c/- Inland Fisheries Research and Development Institute, P.O. Box 582, Phnom Penh, Cambodia; ${ }^{7}$ Centre for Environment, Fisheries and Aquaculture Science, Lowestoft, Suffolk, NR33 OHT, UK; ${ }^{8}$ Department of Biological Sciences, Simon Fraser University, Burnaby, V5A 1S5 Canada
\end{abstract}

\begin{abstract}
Anthropogenic global warming has significantly influenced physical and biological processes at global and regional scales. The observed and anticipated changes in global climate present significant opportunities and challenges for societies and economies. We compare the vulnerability of 132 national economies to potential climate change impacts on their capture fisheries using an indicator-based approach. Countries in Central and Western Africa (e.g. Malawi, Guinea, Senegal, and Uganda), Peru and Colombia in north-western South America, and four tropical Asian countries (Bangladesh, Cambodia, Pakistan, and Yemen) were identified as most vulnerable. This vulnerability was due to the combined effect of predicted warming, the relative importance of fisheries to national economies and diets, and limited societal capacity to adapt to potential impacts and opportunities. Many vulnerable countries were also among the world's least developed countries whose inhabitants are among the world's poorest and twice as reliant on fish, which provides $27 \%$ of dietary protein compared to $13 \%$ in less vulnerable countries. These countries also produce $20 \%$ of the world's fish exports and are in greatest need of adaptation planning to maintain or enhance the contribution that fisheries can make to poverty reduction. Although the precise impacts and direction of climate-driven change for particular fish stocks and fisheries are uncertain, our analysis suggests they are likely to lead to either increased economic hardship or missed opportunities for development in countries that depend upon fisheries but lack the capacity to adapt.
\end{abstract}

Correspondence:

Nicholas K. Dulvy, Centre for Environment, Fisheries and Aquaculture Science, Lowestoft, Suffolk,

NR33 OHT, UK;

Department of Biological Sciences, Simon Fraser University, Burnaby, V5A 1S5 Canada Tel.: (+ 1) 778-782412 Fax: (+1) 1-778-7823496

E-mail: nick_dulvy@ sfu.ca

Received 15 April 2008 Accepted 5 September 2008

Keywords Adaptation, climate change, fisheries, poverty, vulnerability 
Sensitivity or dependence of national economies upon the fisheries sector 182

\section{Introduction}

The world's fisheries provide more than 2.6 billion people with at least $20 \%$ of their average annual per capita protein intake (FAO 2007). As the planet's climate changes so too will populations, species and ecosystems, with profound consequences for fisheries change (Edwards et al. 2002; Harvell et al. 2002; Perry et al. 2005; Stenseth et al. 2005; Lehodey et al. 2006; Hall-Spencer et al. 2008). Where will climate change impacts on fisheries have greatest social and economic significance? This is a simple question, but a comprehensive answer would require predictions of the geographic patterns of global warming (from global circulation models) and predicted impacts of atmospheric warming on climatic, hydrological and oceanographic processes (from physical models). These changes in physical processes would then need to be linked to ecological processes using coupled physical-ecosystem models if they were available (deYoung et al. 2004, Travers et al. 2007; Cury et al. 2008; Jennings and Brander submitted). But all of this takes us only half way to an answer; predicting the impacts on people would further require an understanding of the social and economic dynamics of fishing fleets and fishing communities, and their capacity to adapt to change.

Such integrated predictions of the impact of climate change are beyond the current frontiers of our knowledge, particularly at national or smaller scales. In the meantime, fishers are already being affected by changes that are ultimately driven by rising global atmospheric temperatures. For example, coastal fishers in Bangladesh face increased frequency and severity of hurricanes, coupled with the greater penetration of saline water into coastal land due to thermal expansion of the warming oceans (Unnikrishnan et al. 2006); the people of the Chad basin converge around their shrinking lake, as regional warming drives decreased rainfall and increased evapotranspiration (Coe and Foley 2001); and the coastal fishers cope with bleached coral reefs as atmospheric warming leads, in turn, to warmer seas and higher bleaching susceptibility (Hoegh-Guldberg et al. 2007). Set within a context of overexploitation of many of the world's fisheries (Mullon et al. 2005; Newton et al. 2007), policy makers urgently require information and analysis to guide investments and initiatives in climate change mitigation and adaptation.

While there is a growing body of case studies on the observed effects of climate change on the distribution and production of individual fisheries (e. g. Lehodey et al. 2006; Drinkwater 2005; Kell et al. 2005; Brander 2007), it is difficult to estimate or predict the broader or aggregate effects of climate change at national and regional scales (Brander 2007). Additionally, little attention has been given to the consequences of changing fisheries ecosystems on people, particularly so for the millions of small-scale fisherfolk (fishers, fish processors, traders and ancillary workers) in the developing world who are among the most vulnerable to climate change (Sadovy 2005; McClanahan et al. 2008). Yet informed predictions at these scales are urgently needed, because most policy responses relating to planned climate change adaptation and fisheries management are or will be implemented at national levels (Adger et al. 2005a), and even those at local 
levels will be derived from decisions made at national levels. Until the development of detailed global-scale 'physics-to-fish-to-fishers' models, one pragmatic approach is to use indicators in combination with a risk-assessment or vulnerability framework (Villa and McLeod 2002; Turner et al. 2003; McClanahan et al. 2008).

To date, global and regional climate vulnerability assessments have focused on agricultural production; fisheries have not yet been systematically evaluated (Fischer et al. 2005; Parry et al. 2005; Schmidhuber and Tubiello 2007; Tubiello et al. 2007). In this paper, we provide an indicator-based analysis of the relative vulnerabilities of 132 countries to climate change impacts on fisheries. We use a vulnerability assessment framework developed to identify countries highly exposed to hazards related to climate change, where livelihoods and economic growth depend on climate-sensitive industries, such as agriculture, fisheries, forestry and tourism, and where limited resources, infrastructure and societal capacity constrain adaptation (Turner et al. 2003; Kasperson et al. 2005; Smit and Wandel 2006). Vulnerability is typically defined as a combination of the extrinsic exposure of groups or individuals or ecological systems to a hazard, such as climate change, their intrinsic sensitivity to the hazard, and their lack of capacity to modify exposure to, absorb, and recover from losses stemming from the hazard, and to exploit new opportunities that arise in the process of adaptation (Adger et al. 2005a; Brooks et al. 2005; Smit and Wandel 2006). This analysis is the first systematic attempt to compare the relative vulnerabilities of national economies to potential climate change impacts on fisheries at a global-scale.

\section{Methods}

\section{Spatial scale of climate vulnerability assessment}

We choose to focus on a national scale, mainly because appropriate policies are generally formulated and implemented at this scale, but also because many global indicators are available only at national scale. Country-level assessments provide a broad view of vulnerability patterns and may be used to identify particularly vulnerable regions and eventually facilitate comparison of vulnerability assessments across natural resource-dependent industries, potentially providing insight into processes that cause and exacerbate vulnerability
(Adger et al. 2004; Brooks et al. 2005; Dilley et al. 2005; Yohe et al. 2006). While this analysis may have greatest relevance to the national or international policies that facilitate climate adaptation processes and management of fisheries systems, our approach complements local site-specific assessments looking at individual and fisherfolks' community adaptation (Hamilton et al. 2000; McClanahan et al. 2008; Tuler et al. 2008), as well as case studies investigating the impact of climate change on particular countries or regions (Perry and Sumaila 2007; McGoodwin 2007).

We focus on the vulnerability of national economies to potential impacts of a single large-scale driver, climate change. While additional drivers such as fishing pressure, fuel prices, future changes in trade flows and consumption patterns are important in shaping fisheries production systems, and including such drivers in a global vulnerability analysis with a 50-year horizon would seem pertinent, such long-term global-scale projections are not yet available.

\section{The three components of vulnerability}

Vulnerability to climate change depends upon three key elements: exposure (E) to physical effects of climate change, the degree of intrinsic sensitivity of the natural resource system or dependence of the national economy upon social and economic returns from that sector (S), and the extent to which adaptive capacity (AC) enables these potential impacts to be offset (Adger 2000; IPCC, 2001a). There are no objective, independently derived measures of exposure, sensitivity, or adaptive capacity, and so their relevance and interpretation depend on the scale of analysis, the particular sector under consideration and data availability (Turner et al. 2003; Sullivan and Meigh 2007).

We chose measures of exposure, sensitivity and adaptive capacity that likely to best capture the properties of interest, based on previous vulnerability studies (Brooks et al. 2005; Metzger et al. 2005; O'Brien et al. 2005). The choice of variables is similar to that of other constructed indices such as the Disaster Risk Index, Water Poverty Index and the Hotspots programme (Dilley et al. 2005; Sullivan and Meigh 2007), and was driven by a consideration of a number of factors including: the number of countries for which data were available, the availability of recent data, and the degree of direct relevance to the phenomena that the indicators 
are intended to represent. As this is the first study that specifically addresses the sensitivity of the fishery sector, we identified indicators of economic dependence on fisheries based on a review of the scientific literature (Allison et al. 2005). For the three key elements of vulnerability (i.e. Exposure, Sensitivity, and Adaptive Capacity) the derivation of each indicator is detailed below.

\section{Exposure}

Many climate variables influence fisheries through a range of direct and indirect pathways. The key variables or drivers of interest include: changes in air and water temperatures, precipitation, salinity, ocean circulation and mixing, river flow, nutrient levels, sea and lake levels, ice cover, glacial melt, storm frequency and intensity, and flooding (Barange 2002; Stenseth et al. 2003; Lehodey et al. 2006; Brander 2007). These physical drivers affect fisheries through many pathways; both direct and indirect (Table 1). The known direct effects of climate change include changes in the abundance and distribution of exploited species and assemblages (Perry et al. 2005; Lehodey et al. 2006; Dulvy et al. 2008) and increases in the frequency and severity of extreme events, such as floods and storms, which affect fishing operations and infrastructure (Adger et al. 2005b). Indirect effects include: (i) changes in aquatic habitat quantity and quality, ecosystem productivity and the distribution and abundance of aquatic competitors and predators (O'Reilly et al. 2003; Edwards and Richardson 2004; Hall-Spencer et al. 2008); (ii) impacts on other food production sectors that affect people's livelihoods and food security (Rosegrant and Cline 2003), and (iii) impacts on aspects of people's lives unrelated to their economic activities, such as diseases or damage to their homes (Kovats et al. 2003; Lafferty et al. 2004; Haines et al. 2006).

Choosing an indicator of exposure to climate change for a global analysis is fraught with constraints and assumptions. For countries with marine fisheries, an obvious choice would be changes in sea surface temperature (SST) but there is no equivalent for inland waters, which support significant fisheries in countries such as China, Bangladesh, Cambodia, India and nations in the African Rift Valley. Moreover, even for coastal states, sea surface temperature predictions from global climate models downscaled at the country level were not available at the time of analysis. For climate variables other than temperature, good projections are simply not yet available at the scale of our analysis (IPCC, 2007). We therefore compromised and used projected mean surface air temperature to 2050 as the underlying indicator of exposure to climate change as it is the most direct, best understood and most readily available indicator of future climate change (Table 2; see also Scholze et al. 2006). We thus make the simplifying assumption that warming-related impacts (both positive and negative) upon physical and biological variables affecting fisheries production and fishery operations will be greater in areas where projected air temperature changes are greater.

Using land surface temperature as an indicator of exposure does not account for the specific dynamics of local systems that result in differences between rates of atmospheric warming and surface water heat uptake. However, we note that for the United Kingdom the projected spatial pattern of annual surface warming is similar to the SST warming pattern, but roughly $0.5{ }^{\circ} \mathrm{C}$ warmer (Hulme et al. 2002). While it might be reasonably argued that land surface temperature changes for other areas may not adequately represent the important climate changes over the sea, we note that in at least some parts of the world, particularly the northern hemisphere, SSTs are rising much faster than land surface temperatures (MacKenzie and Schiedek 2007; Sherman et al. 2007; Dulvy et al. 2008). Hence, for such seas, the use of projected land surface temperatures will be a conservative representation of the true exposure of aquatic ecosystems to climate change.

Mean predicted air temperature change at $1.5 \mathrm{~m}$ above the surface for 2050 was derived by rescaling the 2080 values from the TYN CY 3.0 dataset (Mitchell et al. 2004), which provides countryspecific projections based on gridded values from the UK Hadley Centre climate model (HadCM3) outputs (Gordon et al. 2000). The spatial patterns of temperature change are broadly consistent between climate models, so it is reasonable to present results from just one climate model for this level of analysis (IPCC, 2001b). Two IPCC climate change scenarios were selected to represent two contrasting potential futures (IPCC, 2001a). The A1FI world is characterized by a high dependence on fossil fuels, rapid economic growth and continued population growth. These attributes are reflected in higher temperatures than in the $\mathrm{B} 2$ world, in which population growth and economic development are 


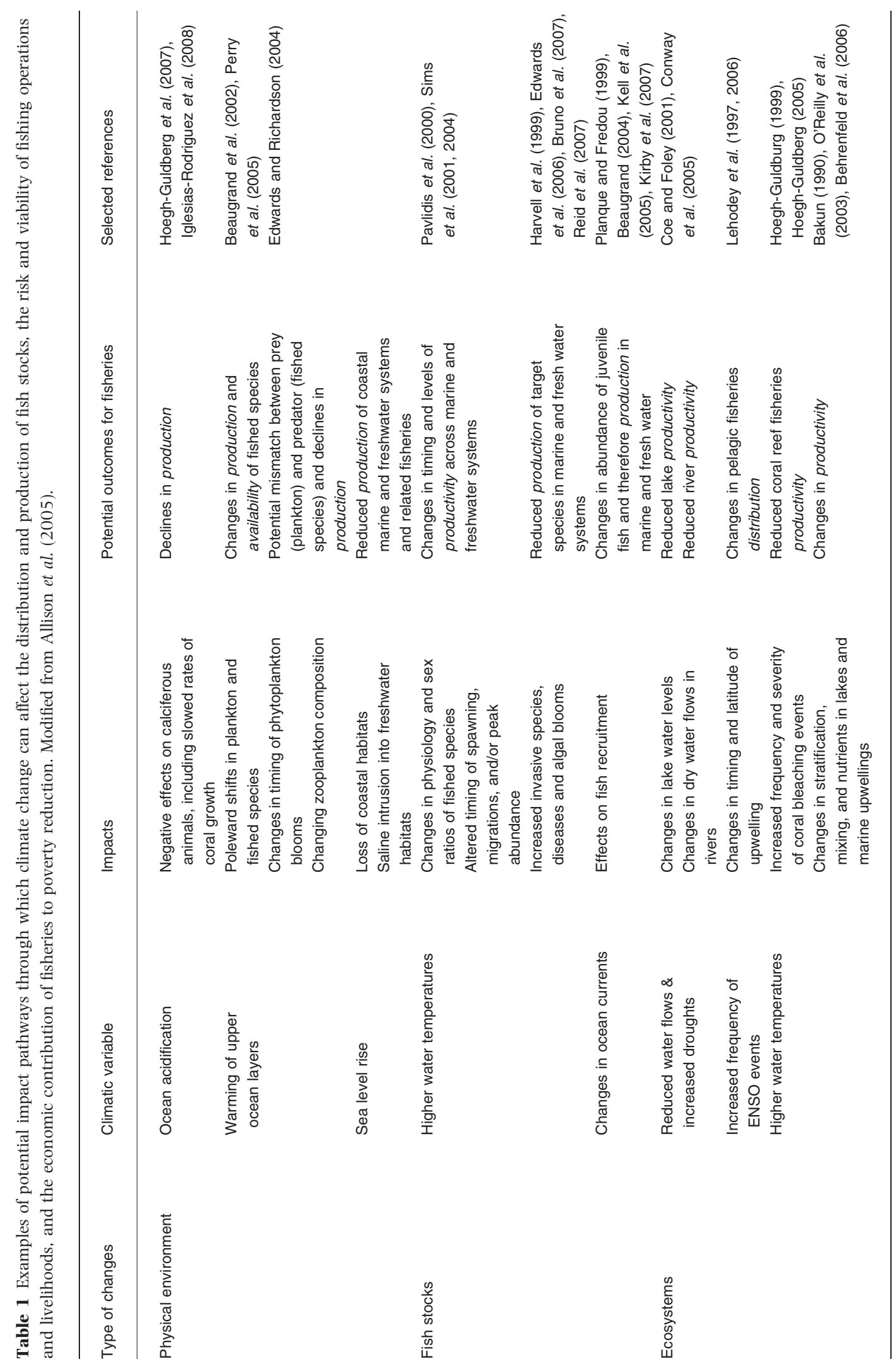

(C) 2009 The Authors

Journal compilation (c 2009 Blackwell Publishing Ltd, FISH and FISHER IES, 10, 173-196 


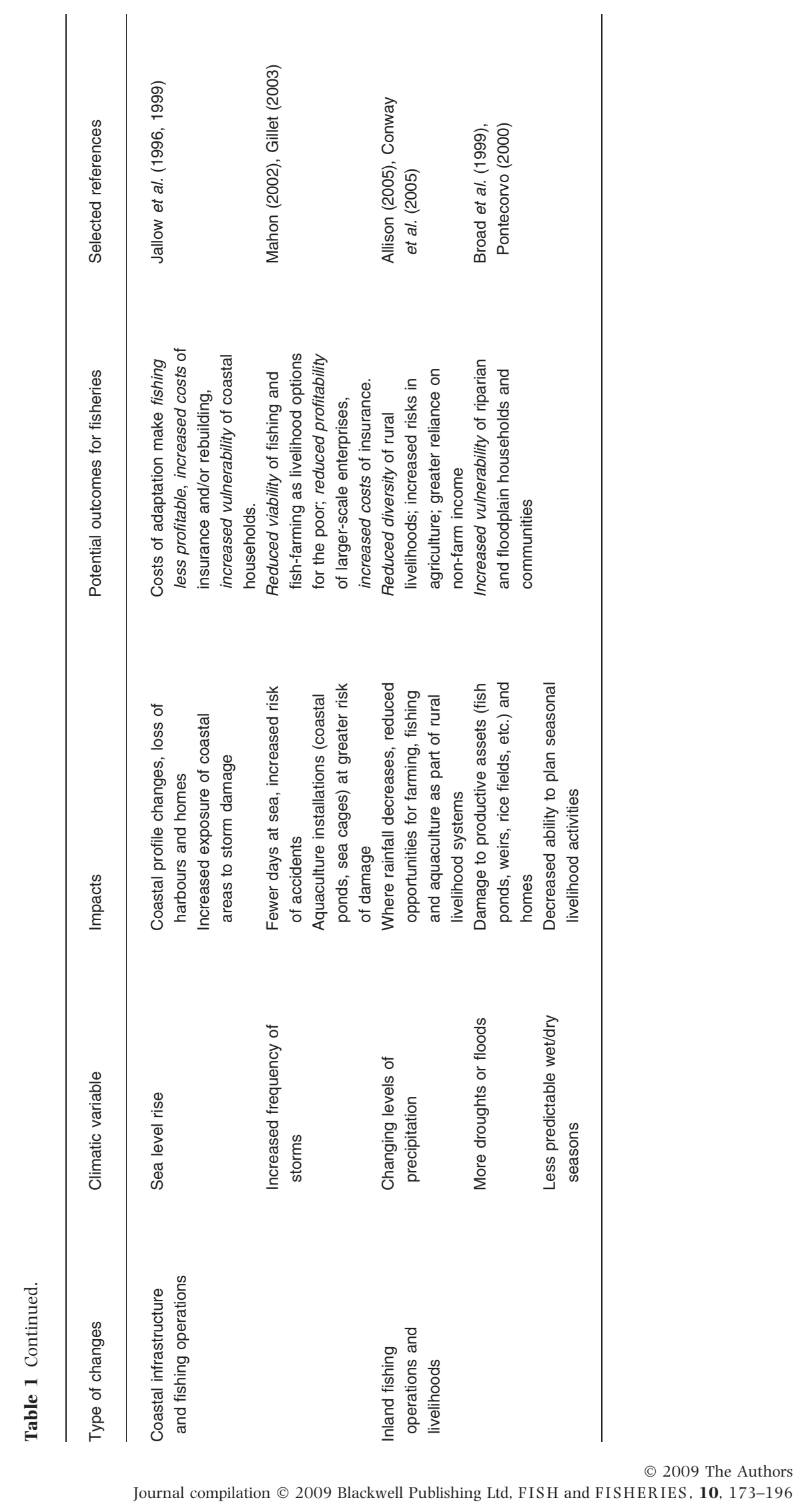


Table 2 Summary of variables used to calculate exposure, sensitivity (as fisheries dependence) and adaptive capacity, and their interpretation.

\begin{tabular}{|c|c|c|c|}
\hline Component & Interpretation & Variable & References \\
\hline Exposure & $\begin{array}{l}\text { Gross indicator of } \\
\text { projected levels } \\
\text { of climate change }\end{array}$ & $\begin{array}{l}\text { Mean projected surface temperature } \\
\text { increase }\left({ }^{\circ} \mathrm{C} \text { at } 1.5 \mathrm{~m} \text { altitude) by } 2050\right.\end{array}$ & Mitchell et al. (2004) \\
\hline \multirow[t]{5}{*}{ Sensitivity } & $\begin{array}{l}\text { Composite index } \\
\text { of employment and }\end{array}$ & $\begin{array}{l}\text { Number of fishers (most recent year } \\
\text { 1990-1996) }\end{array}$ & $\begin{array}{l}\text { FAO (1999); Anonymous } \\
\text { 2003, FAOSTAT } 2004\end{array}$ \\
\hline & $\begin{array}{l}\text { economic dependence } \\
\text { on the fisheries sector }\end{array}$ & $\begin{array}{l}\text { Fisheries export value as proportion (\%) } \\
\text { of total export value (averaged over } \\
\text { 1998-2001) }\end{array}$ & \\
\hline & & $\begin{array}{l}\text { Proportion (\%) of economically active } \\
\text { population (1990) involved in the fishery } \\
\text { sector }\end{array}$ & \\
\hline & & $\begin{array}{l}\text { Total fisheries landings (tonnes, averaged } \\
\text { over 1998-2001) }\end{array}$ & \\
\hline & $\begin{array}{l}\text { Index of nutritional } \\
\text { dependence }\end{array}$ & $\begin{array}{l}\text { Fish protein as proportion of all animal } \\
\text { protein }\left(\% \mathrm{~g} \text { person }{ }^{-1} \text { day }^{-1} \text {, averaged }\right. \\
\text { over } 1998-2001)\end{array}$ & FAOSTAT (2004) \\
\hline \multirow[t]{10}{*}{$\begin{array}{l}\text { Adaptive } \\
\text { capacity }\end{array}$} & Health & Healthy life expectancy (years, 2000) & $\begin{array}{l}\text { Kaufmann et al. (2002), } \\
\text { FAOSTAT (2004), CAIT (2005)) }\end{array}$ \\
\hline & Education & $\begin{array}{l}\text { Literacy rates (\% of people } \geq 15 \text { years, } \\
\text { 2000-2001) }\end{array}$ & CAIT (2005) \\
\hline & & $\begin{array}{l}\text { School enrolment ratios (\% in primary, } \\
\text { secondary and tertiary education, } \\
\text { 2000-2001) }\end{array}$ & \\
\hline & Governance & Political stability & UNDP (2003), CAIT (2005) \\
\hline & (2000-2001) & Government effectiveness & \\
\hline & & Regulatory Quality & \\
\hline & & Rule of law & \\
\hline & & Voice and accountability & \\
\hline & & Corruption & \\
\hline & Size of economy & Total GDP (2000) & CAIT (2005) \\
\hline
\end{tabular}

more moderate and greater emphasis is placed on environmental protection. The exposure index was normalized and rescaled to range from 0 to 1 , with higher values representing higher levels of exposure.

\section{Sensitivity}

Sensitivity is usually defined as the intrinsic degree to which biophysical, social and economic conditions are likely to be influenced by extrinsic stresses or hazards (IPCC, 2001a). However, because climate change may influence ecological and human aspects of fisheries in complex ways, we considered sensitivity in a slightly different context. Instead we assume that the sensitivity, in this context, is represented by the fisheries dependence which we consider to be the importance of fisheries to national economies and food security. In effect, we repre- sented the sensitivity of the economy (and not any single fishery per se) to potential climate-change impacts on the fisheries sector as a whole. The fisheries dependence of national economies was represented using a composite indicator comprised of fisheries production (landings), and the contributions of fisheries to employment, export income and dietary protein (Table 3). This assumes that countries with higher landings and higher contributions of fisheries to employment, export income and dietary protein are more likely to be impacted (positively or negatively) by warming-related changes in the whole fishery production systems of that nation. A composite index of sensitivity was calculated as an unweighted average of the indices of production, economic dependence and nutritional dependence. Resulting values were normalized and scaled to range from 0 to 1 , with higher values reflecting greater sensitivity. 
Vulnerability of national economies Edward H. Allison et al.

\begin{tabular}{|c|c|c|c|c|c|}
\hline Rank & Country & Vulnerability & $E$ & S & $A C$ \\
\hline 1 & Angola & $0.77(2)$ & $0.74(34)$ & $0.60(38)$ & $0.98(1)$ \\
\hline 2 & DR Congo & $0.75(1)$ & $0.65(59)$ & $0.67(20)$ & $0.94(4)$ \\
\hline 3 & $\begin{array}{l}\text { Russian } \\
\text { Federation }\end{array}$ & $0.73(7)$ & $1.00(1)$ & $0.67(22)$ & $0.52(75)$ \\
\hline 4 & Mauritania & $0.73(6)$ & $0.76(26)$ & $0.59(48)$ & $0.83(11)$ \\
\hline 5 & Senegal & $0.72(5)$ & $0.65(59)$ & $0.74(9)$ & $0.78(18)$ \\
\hline 6 & Mali & $0.72(3)$ & $0.74(34)$ & $0.57(57)$ & $0.85(9)$ \\
\hline 7 & Sierra Leone & $0.71(4)$ & $0.50(103)$ & 0.68 (19) & $0.96(3)$ \\
\hline 8 & Mozambique & 0.69 (11) & $0.68(48)$ & $0.59(46)$ & $0.81(13)$ \\
\hline 9 & Niger & $0.69(13)$ & $0.68(48)$ & $0.43(100)$ & $0.97(2)$ \\
\hline 10 & Peru & $0.69(9)$ & $0.82(18)$ & $0.73(10)$ & $0.51(76)$ \\
\hline 11 & Morocco & $0.69(12)$ & $0.74(34)$ & $0.69(16)$ & $0.63(39)$ \\
\hline 12 & Bangladesh & $0.68(8)$ & $0.53(93)$ & $0.80(4)$ & $0.72(32)$ \\
\hline 13 & Zambia & $0.68(21)$ & $0.74(34)$ & $0.54(69)$ & $0.77(20)$ \\
\hline 14 & Ukraine & $0.68(20)$ & $0.91(4)$ & $0.59(42)$ & $0.54(69)$ \\
\hline 15 & Malawi & 0.68 (18) & $0.71(43)$ & $0.55(63)$ & 0.77 (19) \\
\hline 16 & Uganda & $0.68(14)$ & $0.62(69)$ & $0.65(26)$ & $0.76(25)$ \\
\hline 17 & Zimbabwe & $0.67(31)$ & $0.88(7)$ & 0.35 (108) & $0.79(16)$ \\
\hline 18 & Côte d'Ivoire & $0.67(10)$ & $0.56(85)$ & $0.61(34)$ & $0.84(10)$ \\
\hline 19 & Yemen & $0.67(22)$ & $0.68(48)$ & $0.56(61)$ & $0.77(22)$ \\
\hline 20 & Pakistan & 0.67 (15) & $0.62(69)$ & $0.61(32)$ & $0.76(24)$ \\
\hline 21 & Burundi & $0.66(16)$ & $0.59(77)$ & $0.50(84)$ & $0.91(6)$ \\
\hline 22 & Guinea & $0.66(17)$ & $0.59(77)$ & $0.60(37)$ & $0.80(14)$ \\
\hline 23 & Nigeria & $0.65(23)$ & $0.53(93)$ & $0.65(25)$ & $0.78(17)$ \\
\hline 24 & Colombia & $0.65(28)$ & $0.82(18)$ & $0.59(43)$ & $0.54(66)$ \\
\hline 25 & Ghana & $0.65(25)$ & $0.53(93)$ & $0.76(7)$ & $0.66(36)$ \\
\hline 26 & Guinea-Bissau & $0.64(26)$ & $0.56(85)$ & $0.50(83)$ & $0.88(7)$ \\
\hline 27 & Vietnam & $0.64(24)$ & $0.53(93)$ & $0.85(1)$ & $0.55(63)$ \\
\hline 28 & Venezuela & $0.64(32)$ & $0.79(23)$ & $0.60(39)$ & $0.53(71)$ \\
\hline 29 & Algeria & $0.64(36)$ & $0.82(18)$ & $0.46(94)$ & $0.64(38)$ \\
\hline 30 & Cambodia & $0.64(27)$ & $0.56(85)$ & $0.69(18)$ & $0.67(35)$ \\
\hline 31 & $\begin{array}{l}\text { United Republic } \\
\text { of Tanzania }\end{array}$ & $0.64(19)$ & $0.5(103)$ & $0.66(24)$ & $0.75(26)$ \\
\hline 32 & Gambia & $0.63(33)$ & $0.62(69)$ & $0.55(65)$ & $0.73(30)$ \\
\hline 33 & Turkey & $0.63(44)$ & $0.82(18)$ & $0.52(74)$ & $0.55(65)$ \\
\hline
\end{tabular}

Table 3 Relative vulnerabilities of national economies to climate change-driven impacts on fisheries.

The 33 'highly vulnerable' countries (the top quartile of the dataset) are ranked by vulnerability under IPCC scenario B2 (local development, lower emissions); vulnerability rankings under scenario $\mathrm{A} 1 \mathrm{FI}$ (rapid development, high emissions) are presented in parentheses. Index values (rankings) of exposure (E), sensitivity $(S)$ and adaptive capacity (AC) are presented under scenario B2. All rankings are relative to the entire dataset ( $n=132$ countries). Least Developed Countries are listed in bold.

Fisheries production could be represented using either capture fisheries landings (i.e. excluding discards) or catch value. We chose to use fisheries landings for two reasons. First, using catch value would have overweighted the significance of exportled fisheries in relation to fisheries that supply domestic markets, which are generally more important for the well-being and socioecological resilience of local fishing communities (Pauly and Maclean 2003; Sadovy 2005). Second, the monetary value of exports is in any case incorporated elsewhere in the index of dependence (see below). Catch landings for coastal and inland waters were summed across edible fishes, crustaceans and molluscs, and excluding non-edible organisms such as algae, amphibians, aquatic mammals, corals, reptiles, shells and sponges (http://faostat.fao.org/). Annual fisheryrelated export value (US\$) was the sum of exports and re-exports of fishery products fit for human consumption for each country, averaged over 1998-2001 (http://faostat.fao.org/), and expressed as a proportion of total revenues derived from exports of all goods and services, averaged over the same 4-year period (Anonymous, 2003). The FAO 
database does not differentiate exports for aquaculture and capture fisheries, but this bias is likely to have had relatively little effect because aquaculture production (1998 to 2001) was a small fraction of capture production (median $=6.9 \%$ ) for 122 of the 132 countries in the analysis. So while this analysis includes a small element of aquaculture, we have not designed it to fully capture all the details relevant to a comprehensive vulnerability analysis of the aquaculture sector. A preliminary attempt at such an analysis is published elsewhere (Handisyde et al. 2006).

We used two metrics of the contribution of fisheries to national employment: total number of fishers and the number of fishers expressed as a proportion of the economically active population (EAP). These two variables are only weakly correlated (Spearman's $\rho=0.39$ ) and they capture and represent different elements of sensitivity, because strong dependence on fisheries for employment may reflect either high absolute dependence (i.e. a large number of fishers) or relative dependence (i.e. a large proportion of the national workforce), or in some cases, both. Estimates of fisher numbers were derived from the most recent national census data; we caution that these values probably underestimate true numbers because of the recognized difficulties in enumerating fishers (CWP, 2004). The Economically Active Population is the number of employed and unemployed persons (including those persons seeking work for the first time). Values for the EAP are more recent than the estimates of numbers of fishers by 4-9 years. Globally, the number of fishers is increasing faster than the number of farmers, but numbers of fishers may be decreasing in countries in economic transition or undergoing rapid urbanization (Tietze et al. 2000). For individual countries, therefore, this time difference between metrics will merely add to the error variance, rather than introduce systematic bias. Total number of fishers and proportion of fishers in the EAP were averaged to produce a single index of employment-dependence for each country. Due to limited data availability, it was not possible to account for employment within indirect components of the fisheries sector (e.g. manufacture of fishing gear, fish processing), as comparable data were not available across all 133 countries.

The nutritional dependence of the human population on fisheries was represented by the total fish available for consumption per country expressed as a proportion of all consumed animal protein. Fish consumption was estimated as annual total supply (production + imports - exports - non-food uses) from FAO food balance sheets, and expressed as grams of product consumed per person per day (FAOSTAT, 2004).

\section{Adaptive capacity}

Adaptive capacity comprises elements such as levels of social capital, human capital and the appropriateness and effectiveness of governance structures (Haddad 2005; Yohe et al. 2006; Tol and Yohe 2007; Vincent 2007). The adaptive capacity index in this study was a composite of four human development indices (healthy life expectancy, education, governance and size of economy). These variables were chosen on the assumption that countries with high levels of economic and human development have the resources and institutions necessary to undertake planned adaptation (Table 2). The Climate Analysis Indicator Tool (CAIT) developed by the World Resources Institute was used to combine these four variables (CAIT, 2005). CAIT is an information and analysis tool on global climate change, providing a publicly available database of comparable climate-relevant indicators, which are drawn from reputable international and national sources.

Here we outline the four adaptive capacity indicators: healthy life expectancy, education, governance and the size of economy. The variable 'healthy life expectancy' was the number of years a newborn child can expect to live in full health based on current mortality rates and the distribution of health states in the population (WHO, 2002). The link between health and climate change involves opportunity cost, such that countries with significant health burden are likely to find it socially and politically difficult to allocate resources to mitigate and adapt to climate change. Education levels were calculated as a weighted combination of adult literacy and school enrolment rates. Adult literacy was represented by the percentage of people aged $\geq 15$ years that can read and write a simple statement on their everyday life. School enrolment ratio was calculated as the number of students enrolled, regardless of age, as a percentage of the population of official school age for that level for primary, secondary and tertiary gross enrolment (UNDP, 2003). These education variables were weighted $(2 / 3$ literacy rates: $1 / 3$ 
enrolment rates) by CAIT according to United Nations Development Programme methodology (UNDP, 2003). The World Bank governance index combines six equally-weighted components of governance (Kaufmann et al. 2002): political stability (e.g. perceptions of likelihood of armed conflict); government effectiveness (e.g. bureaucratic quality); regulatory quality (e.g. regulatory burden, market-friendliness); rule of law (e.g. black markets, enforceability of contracts); voice and accountability (e.g. free and fair elections, political rights); and corruption (e.g. its prevalence among local officials). Gross Domestic Product (GDP) was calculated as the sum of gross value added by all resident producers in the economy, plus any product taxes, less any subsidies not already included in product values. We used total GDP converted to US dollar values for the year 2000, using purchasing power parity as an indicator of the size of each national economy.

We normalized and standardized the four adaptive capacity indices, averaged them to produce the composite index and then inverted them (1 - index) for inclusion in the vulnerability index, i.e. so that the United States, the country with the greatest adaptive capacity, had the lowest score.

\section{Construction of vulnerability index}

The attributes of vulnerability, exposure (E), sensitivity (S) and AC may be combined in many ways; the form of the relationship among them will be highly context-specific (Turner et al. 2003). For example, the potential impact (PI) of climate change may be seen as a function of exposure or sensitivity, which may be offset, reduced or modified by adaptive capacity, such that $\mathrm{V}=f(\mathrm{PI}-\mathrm{AC})$ or $\mathrm{V}=f([\mathrm{E}, \mathrm{S}]-\mathrm{AC})$. Implicit in this framework is that any vulnerability score is weighted one-half to adaptive capacity and one-quarter each to exposure and sensitivity. A more parsimonious and transparent approach is to avoid such weightings altogether, given that there is not yet a real $a$ priori mechanistic understanding of the relative value and nature of the interaction among their constituent components, by calculating a vulnerability index that simply treats the three components equally, as $\mathrm{V}=f(\mathrm{E}, \mathrm{S}, \mathrm{AC}$ ) (Adger and Vincent 2005). A second issue to consider in calculating a vulnerability index with this framework is whether the variables are averaged (i.e. an additive model) or multiplied. With an additive approach, final vulnerability values depend equally on all three components, while using a multiplicative approach means that a low score on any single component is less likely to result in a high overall vulnerability score (Hajkowicz 2006).

We explored the robustness of vulnerability scores to a variety of methods of combining and weighting exposure, sensitivity and adaptive capacity into a composite index. Different methods of calculation had little effect on the rank order of vulnerability scores for either climate change scenario. Both the weighted (i.e. one-half $\mathrm{AC}$ and one-quarter each for $\mathrm{E}$ and $\mathrm{S}$ ) and unweighted vulnerability scores were highly correlated (A1FI, Pearson's $r=0.96$; B2, $r=0.96$ ). Similarly, averaging or multiplying the variables produced highly correlated vulnerability scores (A1FI, Spearman's $\rho=0.96$; B2, Spearman's $\rho=0.95)$. Indices were therefore calculated as an unweighted mean of the standardized indices of the three components of vulnerability.

A full set of indicators could be calculated for 132 countries. The lack of data resulted in the exclusion of 60 nations, including 21 Least Developed Countries (UN-OHRLLS, 2006) (Fig. 1). Final vulnerability scores were highest for the most vulnerable countries (i.e. high exposure, high sensitivity and low adaptive capacity), and lowest for the least vulnerable countries. For presentation, final indicator scores were categorized into 'high', 'moderate', 'low' and 'very low' quartiles.

\section{Results}

\section{Exposure to climate change}

Under both IPCC scenarios, warming will be greatest in northern parts of Asia, Europe, North America, and South America (Fig. 2). Relatively smaller temperature increases are predicted for nations in Australasia, South Asia, Southeast Asia, western Europe, parts of sub-Saharan Africa, and southern South America. Predicted temperature increases for the final 132 countries in the dataset were very highly correlated between the two scenarios (Spearman's $\rho=0.97, P<0.001$ ).

\section{Sensitivity or dependence of national economies upon the fisheries sector}

The largest fisheries in terms of total capture production and employment were in the Americas 


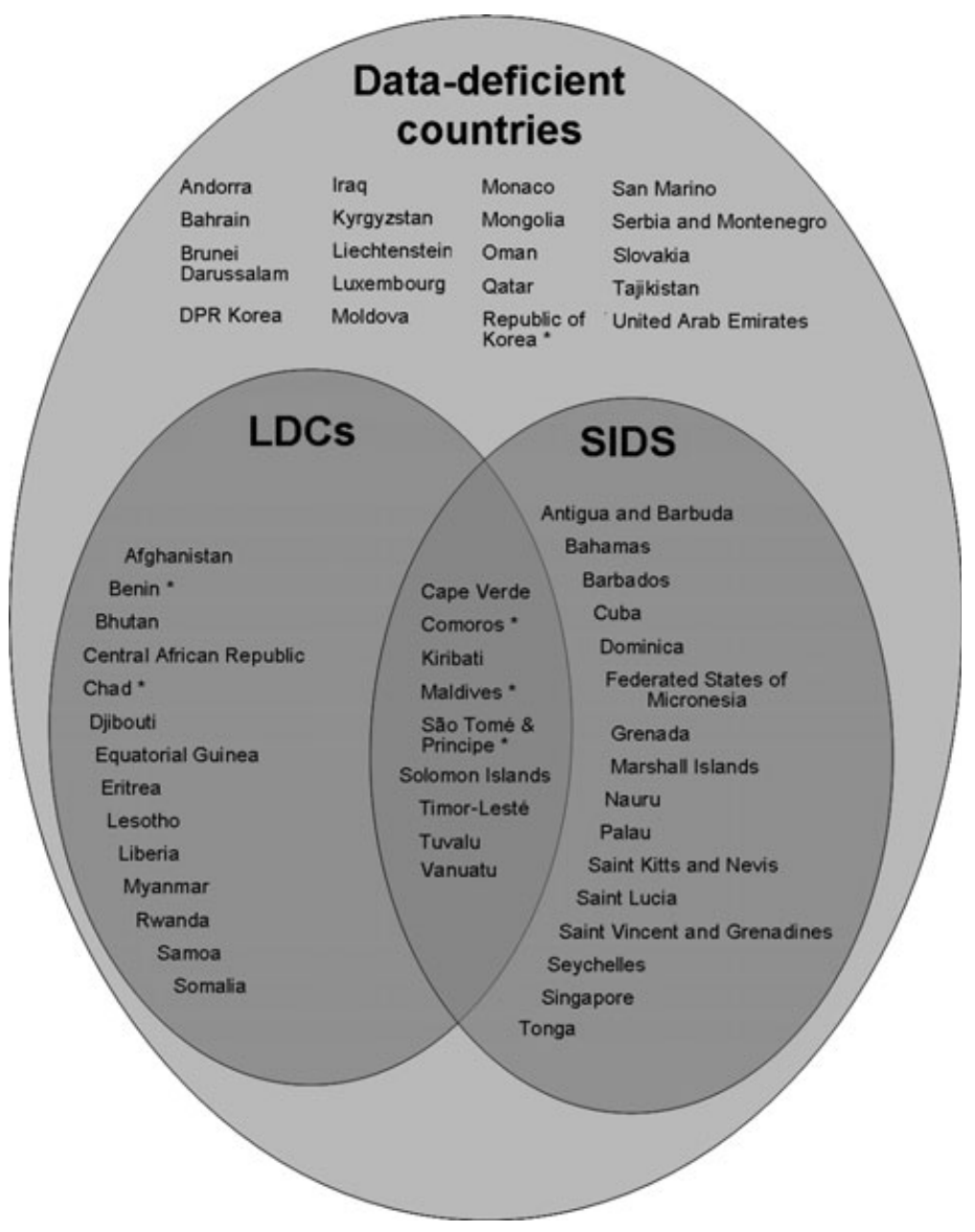

Figure 1 Venn diagram of the distribution of data-deficient countries that could not be included in this analysis, grouped according to Least Developed Countries and Small Island Developing States. * indicates countries for which sensitivity data were available, which were identified as highly fisheries-dependent. This does not include overseas territories.

and in Asia (Figs 3a, b). As expected, the largest reported landings were associated with those countries traditionally considered the world's major fishing nations (FAO, 2007), including China, Peru, Japan, USA, Indonesia, Chile, the Russian Federation, India, Thailand, and Norway. The only Least Developed Country that appeared within the top quartile (i.e. the 33 countries with the highest reported landings) was Bangladesh, which has both significant marine and inland fisheries. African nations were relatively underrepresented within the top quartile, which included only Morocco, Namibia, Nigeria, and Ghana. The lowest levels of production were mainly associated with landlocked countries (e.g. Armenia, Botswana, and Burkina Faso), small island states (e.g. Haiti, Mauritius, and
Trinidad and Tobago), and nations in the Middle East (e.g. Lebanon, Jordan and Kuwait).

Countries with the highest absolute numbers of fishers were concentrated in Asia, Africa and the Americas and included seven Least Developed Countries in Africa and Asia (Bangladesh, Cambodia, DR Congo, Madagascar, Mali, Nepal, and Tanzania). When numbers of fishers were considered in relation to the EAP, the nations most heavily dependent on fisheries for employment (i.e. the top quartile) were located predominantly in Africa and southern Asia (Fig. 3a). Fishers constituted the greatest proportion of the EAP in Fiji, Vietnam, and DR Congo (18.4, 7.4 and 7.1\%, respectively). In three countries (Belize, Malta and Suriname), relatively low absolute numbers of fishers constituted a 


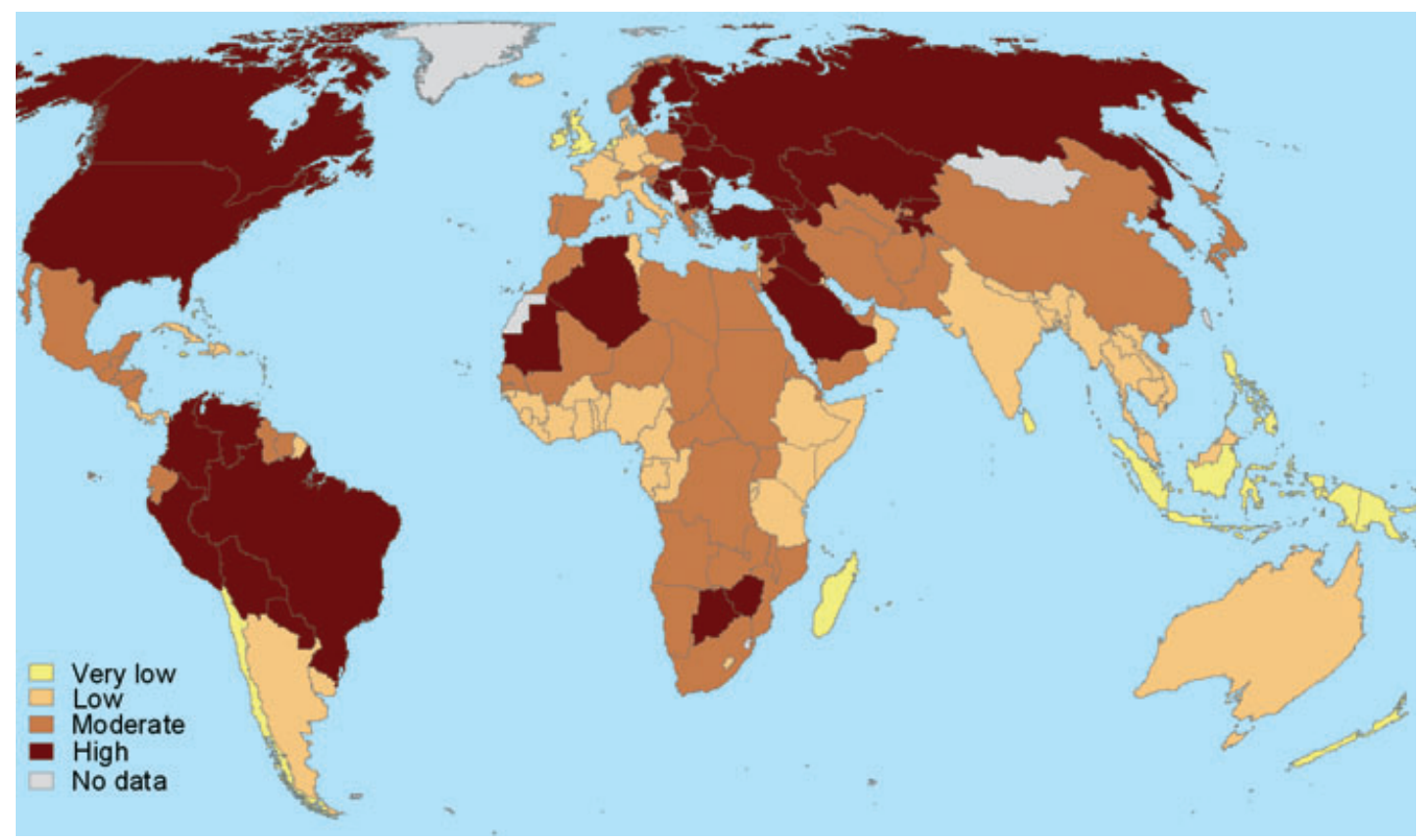

Figure 2 Exposure to climate change, measured as country-specific mean surface temperature increase $\left({ }^{\circ} \mathrm{C}\right.$ at $1.5 \mathrm{~m}$ altitude) by 2050, for IPCC scenario B2, which is a local development scenario assuming modest economic growth based on diverse local development strategies. Colours represent quartiles with dark brown for the upper quartile (highest index value), yellow for the lowest quartile, and grey where no data were available. Data are from the HadCM3 climate model (Gordon et al. 2000) and redrawn from Mitchell et al. (2004).

high proportion of the EAP, while the converse was true in Brazil, Tanzania, Thailand, the Russian Federation, and USA, where relatively high numbers of fishers represented a low proportion of the EAP.

Export income dependency on fisheries was highest in coastal nations of Southeast Asia, Africa, Central and South America, and northern Europe (Fig. 3c). The top quartile of countries with the highest levels of fisheries export income included seven African Least Developed Countries (GuineaBissau, Madagascar, Mauritania, Mozambique, Sierra Leone, Tanzania, and Uganda), as well as Bangladesh and Cambodia. Four high-latitude nations (Denmark, Iceland, Norway, and New Zealand) were also identified as relying heavily on fisheries export incomes; Iceland earned the highest proportion of income from fisheries exports globally.

Nutritional reliance on fish as a source of animal protein was greatest in Asia and sub-Saharan Africa (Fig. 3d). In the three western African countries that were most nutritionally dependent upon fish (i.e. Ghana, Sierra Leone and the Gambia), 59-67\% of animal protein was derived from fish. Many of the countries that were most dependent on fish for protein were Least Developed Countries (13 of the top 33 countries in the final dataset). Three high latitude nations were also strongly reliant on fish protein (i.e. Iceland, Japan and Norway).

Combining the elements of sensitivity revealed that the most fisheries-dependent countries were in Africa, Asia, the Americas, and Europe (Fig. 4a; Table 3). Nations identified as highly dependent on fisheries included seven Least Developed Countries (Bangladesh, Cambodia, DR Congo, Madagascar, Sierra Leone, Tanzania, and Uganda). Of the nations within the top quartile of sensitivity, four scored as strongly dependent on each of the individual components of sensitivity (Bangladesh, Indonesia, Ghana, and Vietnam). The least sensitive quartile included only two countries that were identified as being among the most highly dependent on an individual component of sensitivity: Congo, which was among the most nutritionally reliant on fish (45\% of animal protein derived from fish), and Macedonia, where fishers comprised a relatively high proportion of the workforce $(0.9 \%)$.

Fisheries dependency could not be estimated for 39 countries, of which 14 were Least Developed Countries (Fig. 2). For a further 21 nations, depen- 
dency was estimated but a lack of adaptive capacity data precluded these countries from the final dataset and analyses. Five such countries missing from the final vulnerability analysis were among those identified as most strongly fishery-dependent: Comoros,

\section{(a) Proportion of fishers}

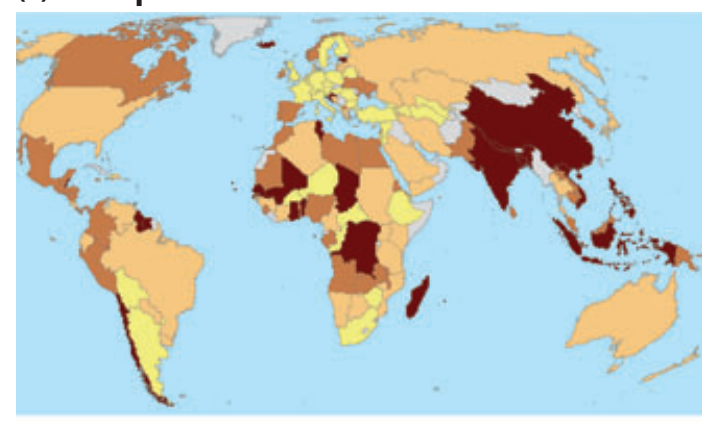

(b) Fisheries landings

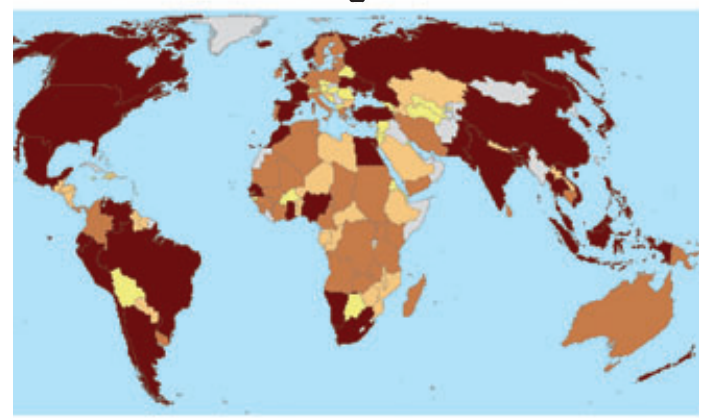

(c) Fish export value

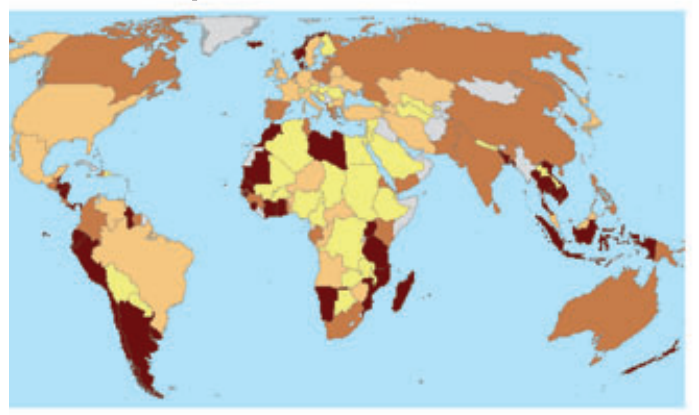

(d) Fish protein

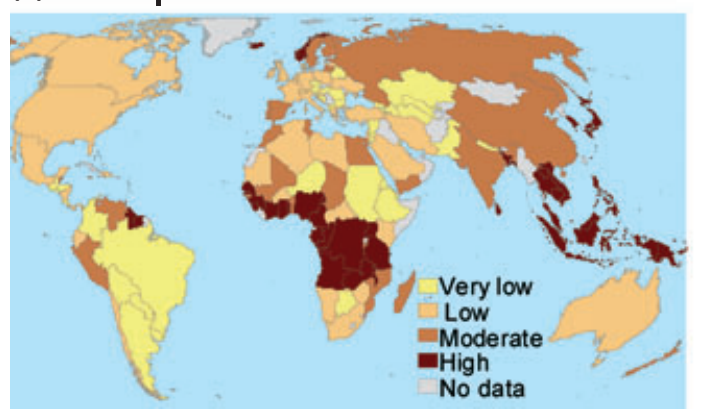

Republic of Korea, Maldives, São Tomé \& Principe, and the Seychelles. For example, the Maldives had the second-highest proportion of fishers within the EAP globally (18\%), and the greatest nutritional dependence on fisheries, with $84 \%$ of animal protein derived from fish (FAOSTAT, 2004).

\section{Adaptive capacity}

The countries with the lowest adaptive capacity were concentrated almost exclusively in Africa and tropical Asia (Fig. 4b). Virtually all Saharan and sub-Saharan African countries, except Namibia, Botswana and South Africa, had low adaptive capacity (Fig. 4b). The Asian countries with lowest adaptive capacity were Pakistan, Bangladesh, Laos PDR and Nepal (Fig. 4b). Yemen and Haiti were also among those countries with the most limited capacity to adapt. Twenty-one countries and territories were excluded from final analyses because adaptive capacity data were not available, including: the island territories of New Caledonia and French Polynesia and 9 Least Developed Countries (Benin, Cape Verde, Central African Republic, Chad, Comoros, Djibouti, Eritrea, Maldives, and São Tomé and Principe).

\section{Vulnerability}

The regions most vulnerable to climate-induced changes in fisheries were in Africa, particularly in the Western Sahel and Central Africa, northwestern South America, and Asia (Yemen, Pakistan, Bangladesh, and Cambodia) (Fig. 5; Table 3). The only highly vulnerable countries in the higher latitudes were Russia and the Ukraine, reflecting their relatively important fishing fleets, high level of exposure to predicted climate change and relatively low adaptive capacity. Half of the highly vulnerable countries (16 out of 31 ) were among Africa's Least Developed Countries, of which one is also a Small Island Developing State (Guinea-Bissau) (Fig. 6).

Figure 3 Dependence of national economies on fisheries. (a) fishers as a proportion of the economically active population, (b) fisheries landings, (c) export value of fisheries products expressed as a proportion of total value of all exports, and (d) fish consumption as a proportion of total animal protein consumption. Colours represent quartiles with dark brown for the upper quartile (highest index value), yellow for the lowest quartile, and grey where no data were available. 


\section{(a) Fisheries sensitivity}

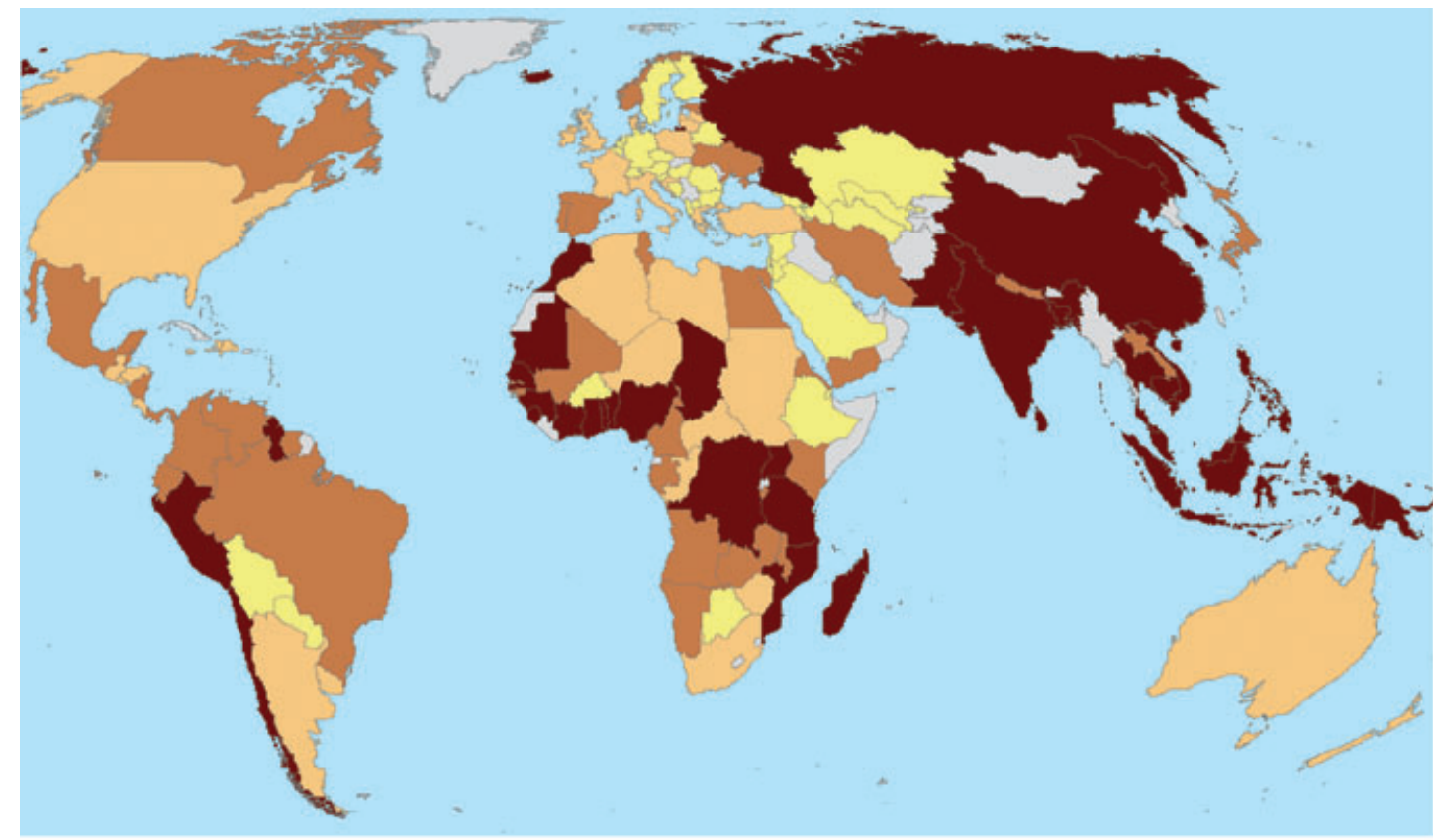

(b) Adaptive capacity

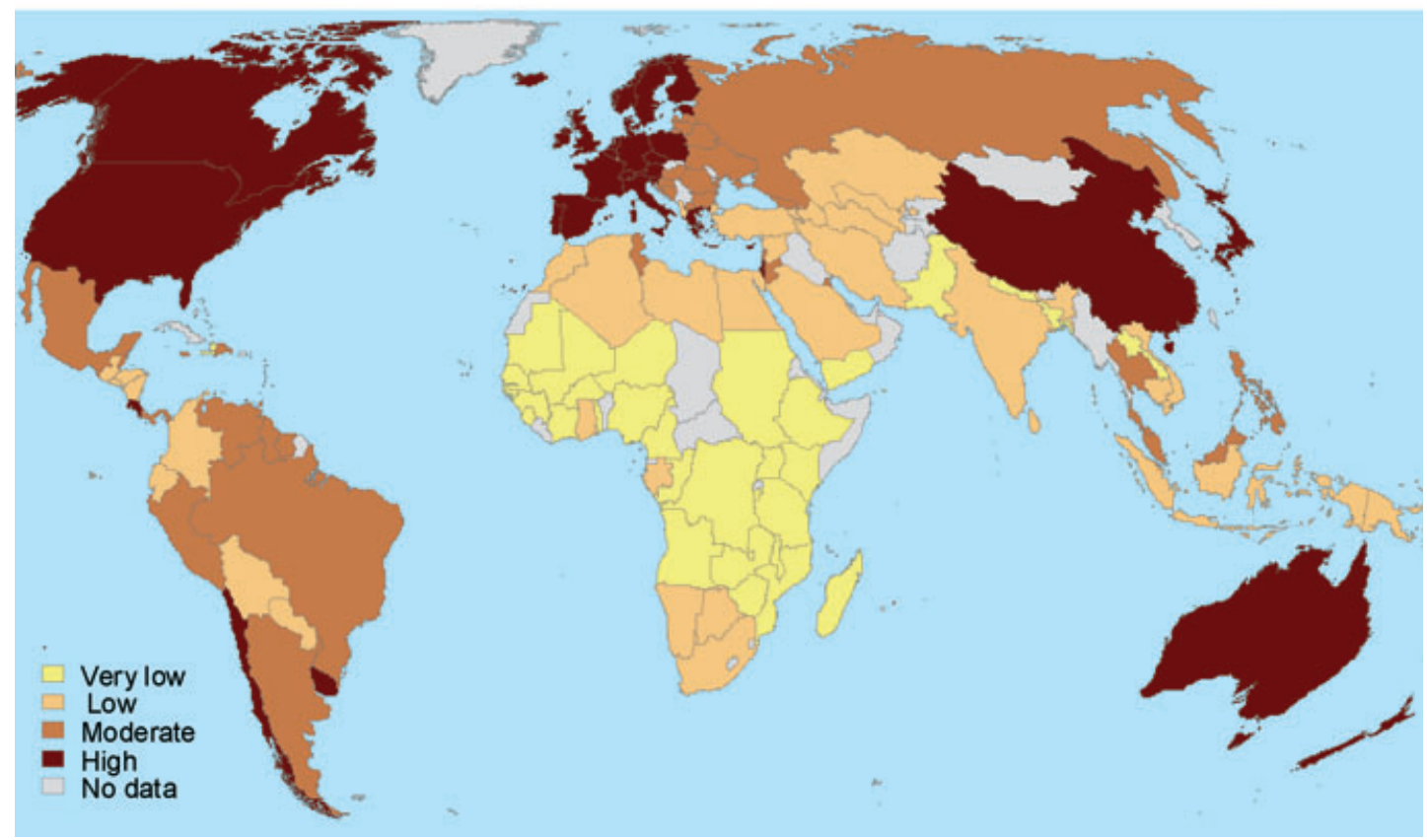

Figure 4 Sensitivity and adaptive capacity of national economies to impacts of climate change on fisheries. (a) Sensitivity as a composite indicator of the fisheries dependence of countries (calculated from number and proportion of fishers, fisheries landings, relative value of fisheries-derived exports and per capita fish protein as a proportion of total animal protein consumed), (b) a composite index of the adaptive capacity of countries (calculated from indices of health, education, governance and size of economy). Colours represent quartiles with dark brown for the upper quartile (highest index value), yellow for the lowest quartile, and grey where no data were available. 


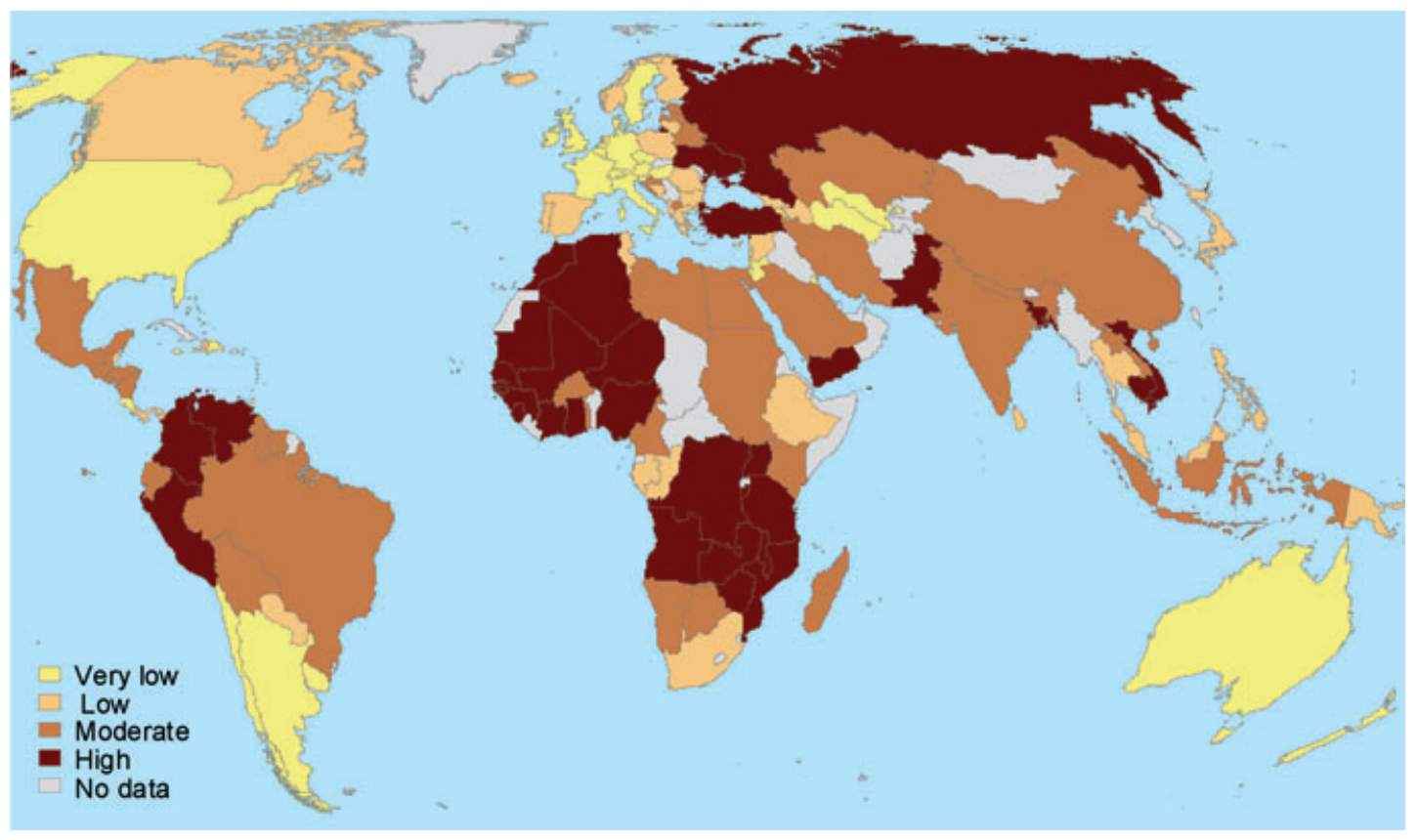

Figure 5 Vulnerability of national economies of potential climate change impacts on fisheries (which integrates exposure, sensitivity and adaptive capacity) under IPCC scenario B2 (local development, lower emissions). Colours represent quartiles with dark brown for the upper quartile (highest index value), yellow for the lowest quartile, and grey where no data were available.

None of the highly vulnerable countries ranked in the upper quartile for all three components of vulnerability. There was little difference in vulnerability between the two climate change scenarios. Algeria and Turkey were vulnerable only under the B2 scenario (Table 3) and Burkina Faso and Togo were vulnerable only under the A1F1 scenario (ranked $26^{\text {th }}$ and $31^{\text {st }}$, respectively).

\section{Discussion}

This study is the first to identify nations whose economies are potentially the most vulnerable to future climate change impacts on the fisheries sector. Although warming will be most pronounced at high latitudes, the countries with economies most vulnerable to warming-related effects on fisheries lie in the tropics. The high vulnerability in each of three regions - Africa, northwestern South America, and Asia - reflects different combinations of climate exposure, sensitivity or fisheries dependence and adaptive capacity. Understanding how these various factors combine to influence vulnerability provides a useful starting point for directing future research and climate change adaptation and mitigation initiatives.
Two-thirds of the most vulnerable countries are in tropical Africa, where fisheries are important to the poor, and regional assessments indicate that fishery production in both continental and marine waters is closely tied to climatic variation. West Coast Sahelian and sub-Saharan countries have large coastal populations that rely upon exploitation of rich marine upwelling fisheries, landings from which are largely driven by irregular low frequency oscillation in oceanic and atmospheric climate conditions (Binet 1997). Fish are an important protein source for some of these West African countries, comprising nearly two-thirds of daily animal protein intake in Gambia, Ghana and Sierra Leone (FAO, 2004). Many of these fisheries are already subject to overfishing by both local, European and East Asian fishing fleets with access agreements (Alder and Sumaila 2004; Brashares et al. 2004). In Eastern and Central African fisheries, landings are derived largely from freshwaters (FAO, 2004). In the deeper Rift Valley lakes, such as Lake Tanganyika, climate change has been associated with increases in surface water temperature, reduced primary productivity and reduced fish catch rate over the last century (O'Reilly et al. 2003). Water levels and surface areas of some large 


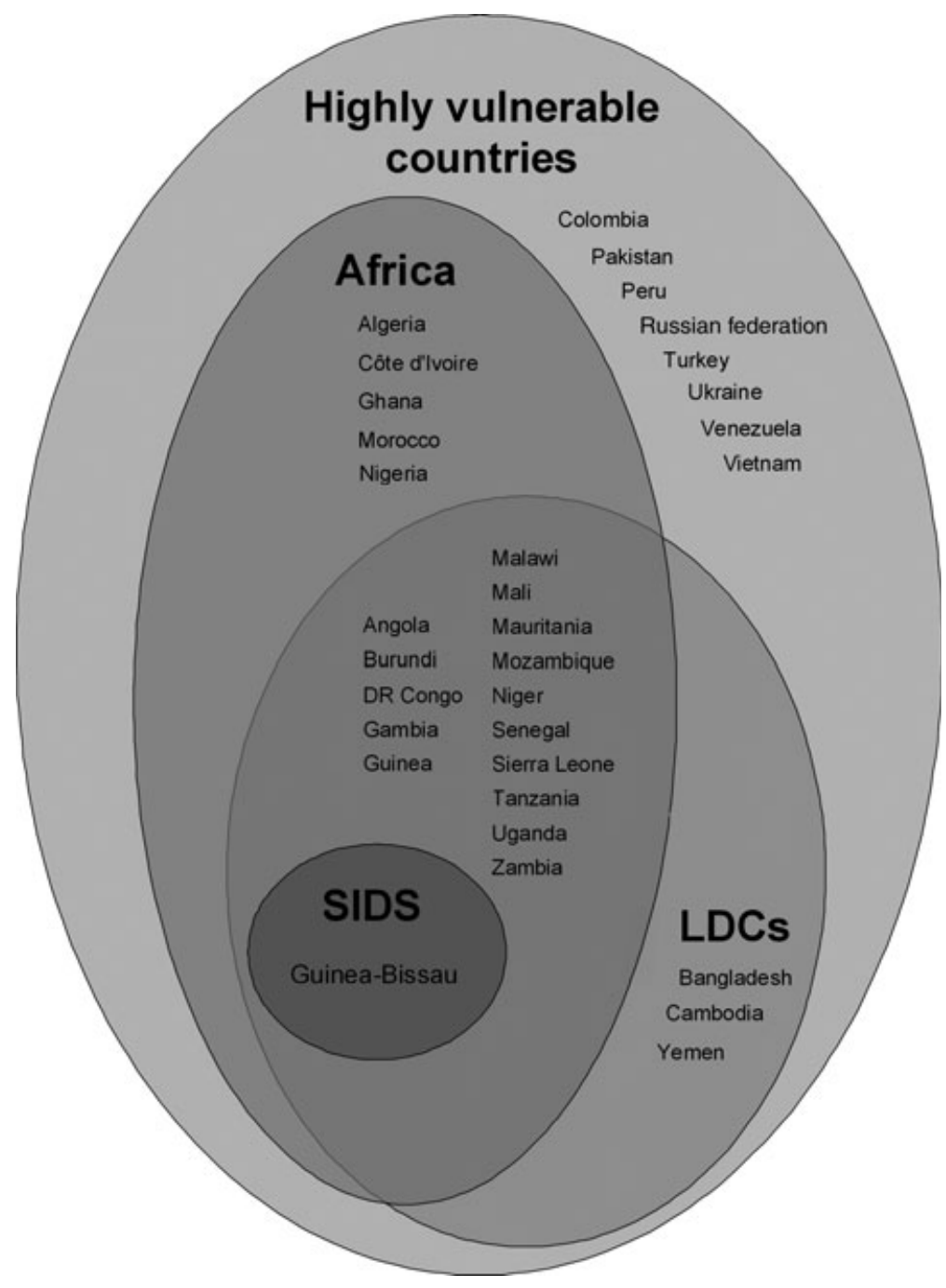

Figure 6 Venn diagram of the distribution of highly vulnerable countries, grouped according to Least Developed Countries, Small Island Developing States and African nations.

shallow African lakes (Lakes Chilwa, Bangweulu and Chad) fluctuate with regional rainfall anomalies (Jul-Larson et al. 2003). These climatic and hydrological fluctuations are mirrored by changes in fishing activity and catches (Allison and Mvula 2002).

Vulnerable Asian countries face combinations of three issues: high fisheries dependence, heavilyexploited marine ecosystems, and high exposure of major riverine and coastal fisheries to climate change. Fish constitute a high proportion of export income in parts of South and Southeast Asia (Fig. 3c), and a major source of dietary protein typically $40 \%$ of all animal protein consumed per year (Fig. 3d). Southeast Asian coral reef fisheries already appropriate four times their sustainable catch and their reefs are heavily at risk from coral bleaching induced by climate change (Bryant et al. 1998; Warren-Rhodes et al. 2003; Newton et al. 2007).

Climate shocks on these Asian fisheries are predicted to have significant economic consequences for the poorest consumers (Briones et al. 2005). Fisheries production of some of the more vulnerable countries in Asia relies on rivers that arise in the Himalayan Mountains - the Indus, Brahmaputra, Ganga and Mekong. Climate change is likely to cause earlier season peak flows and possible reductions in flow, attributable to reduced snowfall and melting glaciers (Barnett et al. 2005). 
For example, predicted summer flows in the Ganges will be reduced by two-thirds (WWF, 2005). The consequences for the region's highly productive river and floodplain fisheries - a vital component of the rural economy - are uncertain and depend on the interaction between local rainfall and glacier melt profiles, the importance of dry vs. wet season water levels for fish productivity, and increasing irrigation demands for domestic, agricultural and industrial use (Vörösmarty et al. 2000; Alcamo et al. 2003).

The relatively high vulnerability of north-western South America largely reflects the globally significant fisheries in this region. Climate-sensitive upwellings of nutrient-rich waters support huge catches of anchovies and sardines, primarily off Peru and Chile (Pauly and Tsukayama 1987; Bakun and Broad 2003). Catches of small pelagic fishes have been as high as 11 million tonnes per year, more than $10 \%$ of world capture fish production (FAO 2004), but show pronounced fluctuations in relation to changes in the El Niño Southern Oscillation (Jacobson et al. 2001). El Niño-related warming effects on upwelling dynamics and productivity are associated with declines in Peruvian anchoveta (Engraulis ringens, Engraulidae), while sardines (Sardinops sagax, Clupeidae) tend to increase (Chavez et al. 2003; Lehodey et al. 2006).

\section{Assumptions, caveats and research gaps}

Our analysis provides a framework for assessing fisheries vulnerability to climate change but there is clearly room to refine this approach as better indicators and models become available. Developing more detailed region-specific predictions about climate change impacts on fisheries will depend on improvements in data and understanding about each of the individual components of vulnerability. Such information is gradually becoming available. Clearly there is an urgent need to develop climate exposure indices that are most appropriate to the range of ecosystems exploited by fisheries. At the global-scale, and considering both marine and freshwater systems, we were restricted to using change in atmospheric surface temperature over countries' landmasses. However, for finer-scale analyses, it would be more appropriate to partition the analysis by biomes (freshwater, coastal or high seas), biogeochemical provinces or Large Marine Ecosystems and to use the most relevant climate drivers in that system or impact pathway as indicators of exposure. For example, projected sea surface temperature and/or primary production might be the appropriate indicators of climate exposure for shelf seas and high seas pelagic fisheries (Nixon 1988; Ware 2000; Jennings et al. 2008, Cheung et al. in press). In contrast, predicted land surface temperatures, precipitation change and/or flow levels may be more appropriate exposure indicators to link to the sensitivity of freshwater ecosystems (Nixon 1988; Payne et al. 1993; Halls et al. 2006). This implies that future analyses should separate inland and marine fisheries, before recombining them for macro-level analyses of the type we have undertaken here. Even when this is done, pathways of impact on fisheries other than through changes in fish production are not considered. These may include increased frequency and severity of storms that claim lives and destroy livelihoods in low-lying tropical coastal areas (Adger et al. 2005b). Our coarse-grained approach at least implicitly incorporates such other potential direct and indirect impact pathways.

We have assumed that average temperature changes within countries will be in some way related to potential impact on fisheries in that nation, and therefore on the economic contribution of those fisheries, but in reality, the fishing sector and its national economic contribution may also be affected by warming in distant regions. Many nations have access agreements to fish in a range of locations around the world, each of which will have varying exposure and sensitivity to climate change. In our dataset, 45 of 132 countries reported distant-water marine landings, which typically represented a small proportion of total marine catches $($ median $=4.9 \%$ ). For five nations, distant-water landings represented the majority of the catch (Belize: 93\%; Lithuania: 77\%; Cyprus: 95\%; Ukraine: $82 \%$; and USA: $98 \% \bar{\equiv}$ f these countries, only the Ukraine was identified as highly vulnerable in our analysis, while the other four nations fell within the two lower quartiles of vulnerability. Assessing in detail the potential scale of distant-water fishery impacts was beyond the scope of this study, but the above figures suggest that this is unlikely to have a major impact on our overall conclusions.

In future, the increasing scale of Global Climate Models coupled with the development of linked regional-scale models of how predicted climate changes are likely to result in changes in productivity and associated catches, such as end-to-end or 
physics-to-fish models will allow a move away from the indicator-based approach outlined here, and provide a more mechanistic approach to parameterising vulnerability analyses. However, there are only a few successful case studies of end-to-end models predicting environmental effects on the abundance, biomass and distribution of single fish species (Megrey et al. 2007; Travers et al. 2007), ecosystems (Jennings et al. 2008) or of commodities, such as fish meal (Mullon and Freon 2005). The development of full climate-forced ecosystem models with fishery, social and economic dynamics may therefore be some way off yet (Dulvy et al. 2009).

A major limitation of large scale vulnerability analyses is the lack of detailed social and economic statistics on the fishing industries and fisheries of nations. The problem is particularly acute for artisanal and subsistence fishers, who tend to be overlooked in national censuses or aggregated into and hidden within the agricultural sector (Sadovy 2005; Andrew et al. 2007). The contribution of fisheries to national economies is often not adequately accounted for; up to $80 \%$ of coastal fisheries landings do not enter the economy (FAO, 1997). Ideally, any vulnerability analysis would be partitioned according to the income distribution and/or poverty levels of national populations. Such detail would contribute substantially to bridging the gap between global-scale analyses, such as this, and appropriate, sectorally-focused national and local scale planning for adaptation.

Insufficient data were available to calculate all three of the component indices of vulnerability for 60 countries, which therefore could not be included in this analysis. For a variety of reasons, many of these countries are likely to have been included in the top quartile of 'highly' vulnerable countries. Some are already suffering great hardship because of war and political unrest. For example, ongoing conflicts in countries such as Chad, Myanmar, Somalia, and Sudan severely limit the adaptive capacity of these nations and place climate change low on list of priorities in the face of more immediate adversity.

Small island states were also underrepresented in this analysis, particularly those in the Pacific Ocean. Absent countries include: Kiribati, Samoa, Solomon Islands, Tuvalu, and Vanuatu, all of which all are also classed as Least Developed Countries (Fig. 2). Kiribati is one of five countries in the world that are entirely comprises of coral atolls (the others are Maldives, and Marshall Islands, and Tokelau, which is a dependency of New Zealand). All of these nations have a high dependence on fish in their citizens' diets, derived from largely unsustainable coral reef fisheries which, along with low elevation, isolation, small size and relative lack of freshwater make them extremely vulnerable to climate change (Nurse and Sem 2001; Barnett and Adger 2003; Newton et al. 2007). The Small Island Developing States that were included in the analysis all scored as being highly vulnerable, (e.g. Fiji, French Polynesia, Maldives, New Caledonia, and the Seychelles), even though they had higher levels of adaptive capacity than many larger countries. In addition, the vulnerability of overseas or dependent territories could not be examined, as their statistics tend to be incorporated into national averages (e.g. of France, UK and USA), while their vulnerability is likely to differ from that of the countries from which they are governed.

Although ecosystems and the services they deliver to people are likely to change markedly over the next 50 years, the causes of those changes and their links to climate change is sometimes less clear. First, fisheries ecosystems and livelihoods will also be affected by climate impacts on other natural resource sectors, and vice versa. Ecosystems that support fisheries, particularly wetlands and river basins, often lie downstream of other human activities (including forestry, agriculture, industrial abstraction and damming) that are likely to compromise and reduce their social and ecological resilience. Second, conversely, where resources are limited, variability in fisheries can lead to increased pressure on terrestrial ecosystems and biodiversity. For example, in Coastal West Africa, during years when small pelagic fishes are in low supply, rates of bushmeat hunting in nature reserves increase, with resulting declines in large terrestrial mammal populations (Brashares et al. 2004). Third, the net contribution of trade to adaptive capacity is worth considering further as fish trade flows from less developed countries to developed countries (Alder and Sumaila 2004). Trade may directly enhance national capacity to respond to threats and hazards through higher total GDP, but may indirectly reduce adaptive capacity by reducing social-ecological resilience (the opposite of vulnerability) at smaller scales (Adger 2000). Fourth, reliance on fisheries may increase further as climate change reduces agricultural crop production (Lobell and Field 2007). South Asia and southern Africa are predicted to suffer most from reduced crop produc- 
tivity and here we suggest these regions will also be vulnerable to the effect of climate change on the fisheries component of national economies.

\section{Conclusions}

Most of the countries that are most vulnerable to climate change impacts on their fisheries are also the poorest: they contribute only $2.3 \%$ of global GDP and 22 of the 33 countries in the most vulnerable quartile are classified as Least Developed Countries. The inhabitants of vulnerable countries are twice as dependent upon fish for food as those of other nations, with $27 \%$ of dietary protein derived from fish compared with 13\% elsewhere. Yet a considerable proportion of fish captured by the most vulnerable nations is exported. The most vulnerable countries produce $20 \%$ of global fishery exports (by weight) totalling US\$6.2 billion (thousand million) or $13 \%$ of the total global value of exports. In the absence of enhanced capacity to cope with and adapt to the impacts of climate change, the disruption of fisheries by climate change is likely to affect large numbers of poor people, and reduce the options for future economic growth in those countries for which fisheries are important sources of food, employment and export revenues.

An important element of climate change that could represent 'dangerous anthropogenic interference' (UNFCCC, 2006) is the vulnerability of the economies of some of the world's fishing countries to climate change impacts which could affect their food security and levels of poverty by elevating stress on fisheries production. While the detailed effects of climate change and direction of change on the physical and biological processes that affect individual fisheries are uncertain, overall, the largescale climate-related changes in fisheries are likely to bring either increased economic hardship or missed opportunities for countries that depend upon them but lack capacity to adapt. Building adaptive capacity is a necessary response, both for countries where climate change may bring improved fishing opportunities and for those where detrimental impacts are foreseen. Countries with weak economies and poor governance are less able to translate improved fishery productivity into reduced poverty. In addition to the effects of climate change, fisheries production systems are already under considerable stress from overfishing, habitat loss, pollution, invasive species, water abstraction and damming. Fortunately most climate change adaptation mea- sures thus go hand-in-hand with attempts to reduce both poverty and overfishing through strengthening livelihoods, economies and environmental governance.

\section{Acknowledgements}

This research was financed by the UK Department for International Development (DfID) Fisheries Management Science Programme and the Department for Environment Food and Rural Affairs (DEFRA), Natural Environment Research Council Quest thematic programme (QUEST-GSI and QUEST-Fish), with support from the Marine Resources Assessment Group (MRAG) and the Centre for Environment, Fisheries and Aquaculture Sciences (Cefas). We thank A. Lovett and C. Houghton for GIS inputs, N. Brooks for advice on vulnerability indicators and S. Dye, C. Howard, A. Payne and J. Pinnegar for commenting on earlier drafts, and two anonymous referees for their careful critical reading of the manuscript and their many constructive suggestions.

\section{References}

Adger, W.N. (2000) Social and ecological resilience: Are they related? Progress in Human Geography 24, 347-364.

Adger, W.N. and Vincent, K. (2005) Uncertainty in adaptive capacity. Comptes Rendus Geoscience 337, 399-410.

Adger, W.N., Brooks, N., Kelly, M., Bentham, S. and Eriksen, S. (2004) New Indicators of Vulnerability and Adaptive Capacity. Technical Report. Tyndall Centre for Climate Change Research. No. 7, Tyndall Centre for Climate Change Research, Norwich.

Adger, W.N., Arnell, N.W. and Tompkins, E.L. (2005a) Successful adaptation to climate change across scales. Global Environmental Change 15, 77-86.

Adger, W.N., Hughes, T.P., Folke, C., Carpenter, S.R. and Rockström, J. (2005b) Social-ecological resilience to coastal disasters. Science 309, 1036-1039.

Alcamo, J., Döll, P., Heinrichs, T. et al. (2003) Global estimates of water withdrawals and availability under current and future business-as-usual conditions. Hydrological Sciences Journal 48, 339-348.

Alder, J. and Sumaila, U.R. (2004) Western Africa: A fish basket of Europe past and present. Journal of Environment and Development 13, 156-178.

Allison, E.H. (2005) The fisheries sector, livelihoods and poverty reduction in Eastern and Southern Africa. In: Rural Livelihoods and Poverty Reduction Policies (eds F. Ellis and H.A. Freeman). Routledge, London, pp. 256-273.

Allison, E.H. and Mvula, P. (2002) Fishing livelihoods and fisheries management in Malawi. Overseas Development 
Group, LADDER Working Paper, University of East Anglia. No. 23.

Allison, E.H., Adger, W.N. and Badjeck, M.-C., et al. (2005) Effects of Climate Change on the Sustainability of Capture and Enhancement Fisheries Important to the Poor: Analysis of the Vulnerability and Adaptability of Fisherfolk Living in Poverty. Fisheries Management Science Programme, DfID, UK. No. R4778J, http://www.fmsp.org.uk, 174 pp.

Andrew, N.L., Bene, C., Hall, S.J., Allison, E.H., Heck, S. and Ratner, B.D. (2007) Diagnosis and management of small-scale fisheries in developing countries. Fish and Fisheries 8, 227-240.

Anonymous (2003) World Development Indicators. The World Bank, Washington D. C., p. 424.

Bakun, A. (1990) Global climate change and intensification of coastal ocean upwelling. Science 247, 198-201.

Bakun, A. and Broad, K. (2003) Environmental 'loopholes' and fish population dynamics: comparative pattern recognition with focus on El Nino effects in the Pacific. Fisheries Oceanography 12, 458-473.

Barange, M. (2002) Influence of climate variability and change on the structure, dynamics and exploitation of marine ecosystems. In: Global Environmental Change. Issues in Environmental Science and Technology (eds R.E. Hester and R.M. Harrison). Royal Society of Chemistry, Cambridge, pp. 57-82.

Barnett, J. and Adger, W.N. (2003) Climate dangers and atoll countries. Climatic Change 61, 321-337.

Barnett, T.P., Adam, J.C. and Lettenmaier, D.P. (2005) Potential impacts of a warming climate on water availability in snow-dominated regions. Nature 438, 303-309.

Beaugrand, G. (2004) The North Sea regime shift: evidence, causes, mechanisms and consequences. Progress in Oceanography 60, 245-262.

Beaugrand, G., Reid, P.C., Ibanez, F., Lindley, J.A. and Edwards, M. (2002) Reorganization of North Atlantic marine copepod biodiversity and climate. Science 296, 1692-1694.

Behrenfeld, M.J., O’Malley, R.T., Siegel, D.A. et al. (2006) Climate-driven trends in contemporary ocean productivity. Nature 444, 752-755.

Binet, D. (1997) Climate and pelagic fisheries in the Canary and Guinea currents 1964-1993: The role of trade winds and the southern oscillation. Oceanologica Acta 20, 177-190.

Brander, K. (2007) Global Fish Production and Climate Change. Proceedings of the National Academy of Sciences 104, 19709-19714.

Brashares, J.S., Arcese, P., Sam, M.K., Coppolillo, P.B., Sinclair, A.R.E. and Balmford, A. (2004) Bushmeat hunting, wildlife declines, and fish supply in West Africa. Science 306, 1180-1183.

Briones, R., Garces, L. and Ahmed, M. (2005) Climate change and small pelagic fisheries in developing Asia: the economic impact on fish producers and consumers.
In: Climate Change and the Economics of the World's Fisheries (eds R. Hannesson, M. Barange and S.F. Herrick Jr). Edward Elgar Publishing, Camberley, UK, pp. 215-235.

Broad, K., Pfaff, A.S.P. and Glantz, M.H. (1999) Climate Information and Conflicting Goals: El Niño 1997-98 and the Peruvian Fishery. Public Philosphy, Environment, and Social Justice. Carnegie Council on Ethics and International Affairs, New York.

Brooks, N., Adger, W.N. and Kelly, M.P. (2005) The determinants of vulnerability and adaptive capacity at the national level and the implications for adaptation. Global Environmental Change 15, 151-163.

Bruno, J.F., Selig, E.R., Casey, K.S. et al. (2007) Thermal Stress and Coral Cover as Drivers of Coral Disease Outbreaks. PLoS Biology 5, e124.

Bryant, D., Burke, L., McManus, J.W. and Spalding, M. (1998) Reefs at Risk, Vol. World Resources Institute, Washington, D. C.

CAIT (2005) Climate Analysis Indicators Tool (CAIT) Version 2.0. http://cait.wri.org/. 2005

Chavez, F.P., Ryan, J., Lluch-Cota, S.E. and Niquen C., M. (2003) From anchovies to sardines and back: multidecadal change in the Pacific Ocean. Science 299, $217-$ 221.

Cheung, W.W.L., Lam, V.W.Y., Sarmiento, J.L., Kearney, K., Watson, R., Pauly, D. (in press) Projecting global marine biodiversity impacts under climate change scenarios. Fish and Fisheries.

Coe, M.T. and Foley, J.A. (2001) Human and natural impacts on the water resources of the Lake Chad basin. Journal of Geophysical Research - Atmospheres 106, 33493356.

Conway, D., Allison, E.H., Felstead, R. and Goulden, M. (2005) Rainfall variability in East Africa: implications for natural resources management and livelihoods. Philosophical Transactions of the Royal Society, A 363. 49-54.

Cury, P.M., Shin, Y.-J. and Planque, B., et al. (2008) Ecosystem oceanography for global change in fisheries. Trends In Ecology \& Evolution. doi: 10.1016/j.tree.2008. 08.005 .

CWP (2004) CWP Handbook of Fishery Statistical Standards. Coordination Working Party on Fisheries Statistics, Food and Agriculture Organisation. http://www.fao.org/ fishery/cwp/search/en.

Dilley, M., Chen, R., Deichmann, U., Lerner-Lam, A. and M., A. (2005) Natural Disaster Hotspots: A Global Risk Analysis. Disaster Risk Management Working Paper Series No. 5 World Bank, Washington D. C., p. 145.

Drinkwater, K.F. (2005) The response of Atlantic cod (Gadus morhua) to future climate change. ICES Journal of Marine Science 62, 1327-1337.

Dulvy, N.K., Rogers, S.I., Jennings, S., Stelzenmüller, V., Dye, S.R. and Skjoldal, H.R. (2008) Climate change and deepening of the North Sea fish assemblage: a biotic 
indicator of regional warming. Journal Of Applied Ecology 45, 1029-1039.

Dulvy, N.K., Hyde, K., Heymans, J.J., Chassot, E., Platt, T. and Sherman, K. (2009) Climate change, ecosystem variability and fisheries productivity. In: Remote Sensing in Fisheries and Aquaculture: The Societal Benefits. Vol. 8 (eds T. Platt, M.-H. Forget and V. Stuart). International Ocean-Colour Coordinating Group, Dartmouth, Canada.

Edwards, M. and Richardson, A.J. (2004) Impact of climate change on marine pelagic phenology and trophic mismatch. Nature 430, 881-884.

Edwards, M., Beaugrand, G., Reid, P.C., Rowden, A.A. and Jones, M.B. (2002) Ocean climate anomalies and the ecology of the North Sea. Marine Ecology Progress Series 239, 1-10.

Edwards, M., Johns, D.G., Leterme, S.C., Svendsen, E. and Richardson, A.J. (2006) Regional climate change and harmful algal blooms in the northeast Atlantic. Limnology and Oceanography 51, 820-829.

FAO (1997) Review of the State of World Fishery Resources: Marine Fisheries. FAO Fisheries Circular. Food and Agriculture Organisation of the United Nations. FAO Fisheries Circular No. 929, Rome, 173pp.

FAO (1999) Number of fishers 1970-1996. FAO Fisheries Circular. No. 929, Rome, 124pp.

FAO (2004) The State of World Fisheries and Aquaculture 2004. Food and Agriculture Organisation, Rome, 153 pp.

FAO (2007) The State of World Fisheries and Aquaculture 2006. Food and Agriculture Organisation of the United Nations, Rome, 180pp.

FAOSTAT (2004) FAO Statistical Databases. http:// faostat.fao.org/.

Fischer, G., Shah, M., Tubiello, F.N. and van Velhuizen, H. (2005) Socio-economic and climate change impacts on agriculture: an integrated assessment, 1990-2080. Philosophical Transactions of the Royal Society B-Biological Sciences 360, 2067-2083.

Gillet, V. (2003) Case Study: The Vulnerability and Adaptive Capacity of the Belize Fisheries Sector to Severe Weather Events. Climate Change and Severe Weather Events in Asia and the Caribbean. Carribean Disaster Emergency Response Agency, Barbados, 33pp.

Gordon, C., Cooper, C., Senior, C.A. et al. (2000) The simulation of SST, sea ice extents and ocean heat transports in a version of the Hadley Centre coupled model without flux adjustments. Climate Dynamics 16, 147-168.

Haddad, B.M. (2005) Ranking the adaptive capacity of nations to climate change when socio-political goals are explicit. Global Environmental Change Part A 15, 165176.

Haines, A., Kovats, R.S., Campbell-Lendrum, D. and Corvalan, C. (2006) Harben Lecture - Climate change and human health: impacts, vulnerability, and mitigation. Lancet 367, 2101-2109.
Hajkowicz, S. (2006) Multi-attributed environmental index construction. Ecological Economics 57, 122-139.

Halls, A.S., Welcomme, R.L. and Burn, R.W. (2006) The relationship between multi-species catch and effort: among fishery comparisons. Fisheries Research 77, 7883.

Hall-Spencer, J.M., Rodolfo-Metalpa, R. and Martin, S., et al. (2008) Volcanic carbon dioxide vents show ecosystem effects of ocean acidification. Nature, $\mathbf{4 5 4}$, 96-99.

Hamilton, L., Lyster, P. and Otterstad, O. (2000) Social change, ecology and climate in 20th century Greenland. Climatic Change 47, 193-211.

Handisyde, N.T., Ross, L.G., Badjeck, M.-C. and Allison, E.H. (2006) The Effects of Climate Change on World Aquaculture: A Global Perspective. Aquaculture and Fish Genetics Research Programme, Stirling Institute of Aquaculture. Final Technical Report, DFID, Stirling. 151pp.

Harvell, C.D., Kim, K., Burkholder, J.M. et al. (1999) Emerging disease - climate links and anthropogenic factors. Science 285, 1505-1510.

Harvell, C.D., Mitchell, C.E., Ward, J.R. et al. (2002) Climate warming and disease risks for terrestrial and marine biota. Science 296, 2158-2162.

Hoegh-Guldberg, O. (2005) Low coral cover in a high- $\mathrm{CO}_{2}$ world. Journal of Geophysical Research C: Oceans 110 , $1-11$.

Hoegh-Guldberg, O., Mumby, P.J., Hooten, A.J. et al. (2007) Coral reefs under rapid climate change and ocean acidification. Science 318, 1737-1742.

Hoegh-Guldburg, O. (1999) Climate change, coral bleaching and the future of the world's coral reefs. Marine and Freshwater Research 50, 839-866.

Hulme, M., Jenkins, G.J. and Lu, X. et al. (2002) Climate Change Scenarios for the United Kingdom: The UKCIPO2 Scientific Report. Tyndall Centre for Climate Change Research, School of Environmental Sciences, University of East Anglia, Norwich, UK. 120pp.

Iglesias-Rodriguez, M.D., Halloran, P.R., Rickaby, R.E.M. et al. (2008) Phytoplankton Calcification in a High-CO2 World. Science 320, 336-340.

IPCC (2001a) Climate Change 2001: Impacts, Adaptation \& Vulnerability, Contribution of Working Group II to the Third Assessment Report of the Intergovernmental Panel on Climate Change, Vol. Cambridge University Press, Cambridge.

IPCC (2001b) Climate Change 2001: The Scientific Basis. Contribution of Working Group I to the Third Assessment Report of the Intergovernmental Panel on Climate Change, Vol., Cambridge University Press, Cambridge.

IPCC (2007) Climate Change 2007: The Physical Science Basis. Summary for Policymakers. Intergovernmental Panel on Climate Change, Geneva, 18pp.

Jacobson, L.D., De Oliveira, J.A.A., Barange, M. et al. (2001) Surplus production, variability, and climate change in the great sardine and anchovy fisheries. 
Canadian Journal Of Fisheries and Aquatic Sciences $\mathbf{5 8}$, 1891-1903.

Jallow, B.P., Barrow, M.K.A. and Leatherman, S.P. (1996) Vulnerability of the coastal zone of the Gambia to sea level rise and development of response strategies and adaptation options. Climate Research 6, 165177.

Jallow, B.P., Toure, S., Barrow, M.M.K. and Mathieu, A.A. (1999) Coastal zone of The Gambia and the Abidjan region in Cote d'Ivoire: Sea level rise vulnerability, response strategies, and adaptation options. Climate Research 12, 129-136.

Jennings, S. and Brander, K. (submitted) Predicting the effects of climate variation and change on marine communities and the consequences for fisheries. Journal of Marine Systems.

Jennings, S., Mélin, F., Blanchard, J.L., Forster, R.M., Dulvy, N.K. and Wilson, R.W. (2008) Global-scale predictions of community and ecosystem properties from simple ecological theory. Proceedings of the Royal Society B: Biological Sciences 275, 1375-1383.

Jul-Larson, E., Kolding, J., Overå, R., Raakjær Nielsen, J. and van Zwieten, P.A.M. (2003) Management, co-Management or no Management? Major Dilemmas in Southern African Freshwater Fisheries. 1. Synthesis report. Food and Agriculture Organisation, UN. FAO Fisheries Technical Paper. No. 426/1.

Kasperson, R.E., Dowe, K., Archer, E. et al. (2005) Vulnerable people and places. In: Ecosystems and Human Well-Being: Current Trends and Status. Vol. 1 (eds R. Hassan, R. Scholes and N. Ash). Island Press, Washington, pp. 143-164.

Kaufmann, D., Kraay, A. and Zoido-Lobatén, P. (2002) Governance Matters II: Updated Indicators for 2000/1. World Bank Policy Research Working Paper. No. 2772, Washington D. C., 60pp.

Kell, L.T., Pilling, G.M. and O'Brien, C.M. (2005) Implications of climate change for the management of North Sea cod (Gadus morhua). ICES Journal Of Marine Science 62, 1483-1491.

Kirby, R.R., Beaugrand, G., Lindley, J.A., Richardson, A.J., Edwards, M. and Ried, C.P.R. (2007) Climate effects and benthic-pelagic coupling in the North Sea. Marine Ecology Progress Series 330, 31-38.

Kovats, R.S., Hajat, S., Bouma, M.J., Worrall, E. and Haines, A. (2003) El Niño and health. Lancet 362, 1481-1489.

Lafferty, K.D., Porter, J.W. and Ford, S.E. (2004) Are diseases increasing in the ocean? Annual Review of Ecology, Evolution, and Systematics 35, 31-54.

Lehodey, P., Bertignac, M., Hampton, J., Lewis, A. and Picaut, J. (1997) El Niño Southern Oscillation and tuna in the western Pacific. Nature 389, 715-718.

Lehodey, P., Alheit, J., Barange, M. et al. (2006) Climate variability, fish and fisheries. Journal of Climate 19 , 5009-5030.
Lobell, D.B. and Field, C.B. (2007) Global scale climate crop yield relationships and the impacts of recent warming. Environmental Research Letters 2, 14-21.

MacKenzie, B.R. and Schiedek, D. (2007) Daily ocean monitoring since the 1860s shows record warming of northern European seas. Global Change Biology 13 , 1335-1347.

Mahon, R. (2002) Adaptation of Fisheries and Fishing Communities to the Impacts of Climate Change in the CARICOM Region. Mainstreaming Adaptation to Climate Change (MACC) of the Caribbean Center for Climate Change (CCCC), Organization of American States, Washington, D. C., 33pp.

McClanahan, T.R., Cinner, J.E., Maina, J. et al. (2008) Conservation action in a changing climate. Conservation Letters 1, 53-59.

McGoodwin, J.R. (2007) Effects of climatic variability on three fishing economies in high-latitude regions: Implications for fisheries policies. Marine Policy 31, 40-55.

Megrey, B.A., Rose, K.A., Klumb, R.A. et al. (2007) A bioenergetlics-based population dynamics model of Pacific herring (Clupea harengus pallasi) coupled to a lower trophic level nutrient-phytoplankton-zooplankton model: Description, calibration, and sensitivity analysis. Ecological Modelling 202, 144-164.

Metzger, M., Leemans, R. and Schröter, D. (2005) A multidisciplinary multi-scale framework for assessing vulnerability to global change. International Journal of Applied Earth Observation and Geoinformation 7, 253267.

Mitchell, T.D., Carter, T.R., Jones, P.D., Hulme, M. and New, M. (2004) A Comprehensive set of High Resolution Grids of Monthly Climate for Europe and the Globe: The Observed Record (1901-2000) and 16 Scenarios (20012100). Tyndall Centre Working Paper 55, Tyndall Centre for Climate Change Research, Norwich.

Mullon, C. and Freon, P. (2005) Prototype of an integrated model of the worldwide system of small pelagic fishes. In: Climate Change and the Economics of the World's Fisheries (eds R. Hannesson, M. Barange and S.F. Herrick Jr). Edward Elgar Publishing, Camberley, UK, pp. 262-295. Mullon, C., Freon, P. and Cury, P. (2005) The dynamics of collapse in world fisheries. Fish and Fisheries 6, 111120.

Newton, K., Côté, I.M., Pilling, G.M., Jennings, S. and Dulvy, N.K. (2007) Current and future sustainability of island coral reef fisheries. Current Biology 17, 655658.

Nixon, S.W. (1988) Physical energy inputs and the comparative ecology of lake and marine ecosystems. Limnology \& Oceanography 33, 1005-1025.

Nurse, L.A. and Sem, G. (2001) Small island states. In: Climate Change 2001: Impacts, Adaptation and Vulnerability (eds J.J. McCarthy, O.F. Canziani, N.A. Leary, D.J. Dokken and K.S. White). Cambridge University Press, Cambridge, pp. 843-875. 
O’Brien, K., Leichenko, R., Kelkar, U. et al. (2005) Mapping vulnerability to multiple stressors: climate change and globalization in India. Global Environment Change 14, 303-313.

O'Reilly, C.M., Alin, S.R., Plisnier, P.D., Cohen, A.S. and McKee, B.A. (2003) Climate change decreases aquatic ecosystem productivity of Lake Tanganyika, Africa. Nature 424, 766-768.

Parry, M., Rosenzweig, C. and Livermore, M. (2005) Climate change, global food supply and risk of hunger. Philosophical Transactions of the Royal Society, B $\mathbf{3 6 0}$, 2125-2138.

Pauly, D. and Maclean, J. (2003) In a Perfect Ocean: fisheries and ecosystems in the North Atlantic, Island Press, Washington, p. 175.

Pauly, D. and Tsukayama, I. (1987) The Peruvian Anchoveta and its Upwelling Ecosystem: Three Decades of Change. Vol. 15. ICLARM Studies and Reviews, Manila, Philippines.

Pavlidis, M., Koumoundouros, G., Sterioti, A., Somarakis, S., Divanach, P. and Kentouri, M. (2000) Evidence of temperature-dependent sex determination in the European sea bass (Dicentrarchus labrax L.). Journal of Experimental Zoology 287, 225-232.

Payne, A.I., Crombie, J., Halls, A.S. and Temple, S.A. (1993) Synthesis of Simple Predictive Models for Tropical River Fisheries. Fisheries Management Science Programme, Overseas Development Administration, London, 85pp.

Perry, R.I. and Sumaila, U.R. (2007) Marine ecosystem variability and human community responses: The example of Ghana, West Africa. Marine Policy 31 , 125-134.

Perry, A.L., Low, P.J., Ellis, J.R. and Reynolds, J.D. (2005) Climate change and distribution shifts in marine fishes. Science 308, 1912-1915.

Planque, B. and Fredou, T. (1999) Temperature and the recruitment of Atlantic cod (Gadus morhua). Canadian Journal Of Fisheries and Aquatic Sciences 56, 2069-2077.

Pontecorvo, G. (2000) ENSO, Regime Shifts, the Peruvian Anchoveta Catch and Fisheries Management: Some Prelim Inary Observations. (Proceedings of the IIFET 2000: Microbehaviour and Macroresults, Corvalis, Oregon, 2000). International Institute of Fisheries Economics and Trade, City.

Reid, P.C., Johns, D.G., Edwards, M., Starr, M., Poulin, M. and Snoeijs, P. (2007) A biological consequence of reducing arctic sea ice cover: arrival of the Pacific diatom Neodenticulata seminae in the North Atlantic for the first time in 800,000 years. Global Change Biology 13, 1910-1921.

Rosegrant, M.W. and Cline, S.A. (2003) Global food security: challenges and policies. Science 302, 1917-1919.

Sadovy, Y. (2005) Trouble on the reef: the imperative for managing vulnerable and valuable fisheries. Fish and Fisheries 6, 167-185.
Schmidhuber, J. and Tubiello, F.N. (2007) Global food security under climate change. Proceedings of the National Academy of Sciences 104, 19703-19708.

Scholze, M., Knorr, W., Arnell, N.W. and Prentice, I.C. (2006) A climate-change risk analysis for world ecosystems. PNAS 103, 13116-13120.

Sherman, K., Belkin, I., O’Reilly, J.E. and Hyde, K. (2007) Variability of Large Marine Ecosystems in response to global climate change. International Council for Exploration of the Seas 2007, D:20.

Sims, D.W., Genner, M.J., Southward, A.J. and Hawkins, S.J. (2001) Timing of squid migration reflects North Atlantic climate variability. Proceedings of the Royal Society of London, B 268, 2607-2611.

Sims, D.W., Wearmouth, V.J., Genner, M.J., Southward, A.J. and Hawkins, S.J. (2004) Low-temperature-driven early spawning migration of a temperate marine fish. Journal Of Animal Ecology 73, 333-341.

Smit, B. and Wandel, J. (2006) Adaptation, adaptive capacity and vulnerability. Global Environmental Change 16, 282-292.

Stenseth, N.C., Ottersen, G. and Hurrell, J.W., et al. (2003) Studying climate effects on ecology through the use of climate indices: the North Atlantic Oscillation, El Nino Southern Oscillation and beyond. Proceedings of the Royal Society Of London Series B-Biological Sciences $\mathbf{2 7 0}$, 2087-2096. [In English].

Stenseth, N.C., Ottersen, G., Hurrell, J.W. and Belgrano, A. (2005) Marine Ecosystems and Climate Variation, Oxford University Press, Oxford, p. 252.

Sullivan, C.A. and Meigh, J. (2007) Integration of the biophysical and social sciences using an indicator approach: Addressing water problems at different scales. Water Resources Management 21, 111-128.

Tietze, U., Groenewold, G. and Marcoux, A. (2000) Demographic Change in Coastal Fishing Communities and its Implications for the Coastal Environment. Food and Agriculture Organisation of the United Nations. Fisheries Technical Paper. No. 403, Rome 151pp.

Tol, R.S.J. and Yohe, G.W. (2007) The weakest link hypothesis for adaptive capacity: An empirical test. Global Environmental Change-Human and Policy Dimensions 17, 218-227.

Travers, M., Shin, Y.J., Jennings, S. and Cury, P. (2007) Towards end-to-end models for investigating the effects of climate and fishing in marine ecosystems. Progress in Oceanography 75, 751-770.[In English].

Tubiello, F.N., Soussana, J.F. and Howden, S.M. (2007) Crop and pasture response to climate change. Proceedings Of the National Academy Of Sciences Of the United States Of America 104, 19686-19690.

Tuler, S., Agyeman, J., da Silva, P.P., LoRusso, K.R. and Kay, R. (2008) Assessing vulnerabilities: Integrating information about driving forces that affect risks and resilience in fishing communities. Human Ecology Review 15, 171-184.[In English]. 
Turner, B.L., Kasperson, R.E., Matsone, P.A. et al. (2003) A framework for vulnerability analysis in sustainability science. Proceedings of the National Academy Of Sciences Of the United States Of America 100, 8074-8079.

UNDP (2003) Human development indicators 2003. Human Development Report Office, United Nations Development Programme.

UNFCCC (2006) UN Framework Convention on Climate Change - Article 2 text. http://unfccc.int/essential_background/convention/background/items/1353.php.

Unnikrishnan, A.S., Kumar, K.R., Fernandes, S.E., Michael, G.S. and Patwardhan, S.K. (2006) Sea level changes along the Indian coast: Observations and projections. Current Science 90, 362-368.

UN-OHRLLS (2006) Least Developed Countries: about least developed countries. http://www.un.org/special-rep/ ohrlls/ldc/list.htm. 13 MArch 2008

Villa, F. and McLeod, H. (2002) Environmental vulnerability indicators for environmental planning and decision-making: Guidelines and applications. Environmental Management 29, 335-348. [In English].

Vincent, K. (2007) Uncertainty in adaptive capacity and the importance of scale. Global Environmental ChangeHuman and Policy Dimensions 17, 12-24.

Vörösmarty, C.J., Green, P.J., Salisbury, J. and Lammers, R.B. (2000) Global water resources: vulnerability from climate change and population growth. Science $\mathbf{2 8 9}$ 284-288.

Ware, D.M. (2000) Aquatic ecosystems: properties and models. In: Fisheries Oceanography: And Integrative Approach to Fisheries Ecology and Management (eds P.J. Harrison and T.R. Parsons). Blackwell Science, Oxford, pp. 267-295.

Warren-Rhodes, K., Sadovy, Y. and Cesar, H. (2003) Marine ecosystem appropriation in the Indo-Pacific: A case study of the live reef fish food trade. Ambio $\mathbf{3 2}$, 481-488.

WHO (2002) Reducing Risks, Promoting Healthy Life. World Health Organisation.

WWF (2005) An overview of glaciers, glacier retreat and subsequent impacts in Nepal, India and China. World Wildlife Foundation. p. 70.

Yohe, G., Malone, E. and Brenkert, A., et al. (2006) A Synthetic Assessment of the Global Distribution of Vulnerability to Climate Change From the IPCC Perspective That Reflects Exposure and Adaptive Capacity. CIESIN (Center for International Earth Science Information Network), Columbia University, Palisades. http://ciesin.columbia. edu/data/climate/ Access date July 8, 2008.

deYoung, B., Heath, M., Werner, F., Chai, F., Megrey, B. and Monfray, P. (2004) Challenges of modeling ocean basin ecosystems. Science 304, 1463-1466. 